\title{
Stem Cell-Based Tissue Engineering for the Treatment of Burn Wounds: A Systematic Review of Preclinical Studies
}

\author{
Alissa Olga Lukomskyj ${ }^{1} \cdot$ Nikitha Rao $^{2} \cdot$ Lei Yan $^{3}$ - Jasmine Sarah Pye ${ }^{2} \cdot$ Haiyan $\mathrm{Li}^{4} \cdot$ Bin Wang ${ }^{3,5} \cdot$ Jiao Jiao Li ${ }^{1,2}$ (i)
}

Accepted: 21 January 2022 / Published online: 12 February 2022

(c) The Author(s) 2022

\begin{abstract}
Burn wounds are a devastating type of skin injury leading to severe impacts on both patients and the healthcare system. Current treatment methods are far from ideal, driving the need for tissue engineered solutions. Among various approaches, stem cell-based strategies are promising candidates for improving the treatment of burn wounds. A thorough search of the Embase, Medline, Scopus, and Web of Science databases was conducted to retrieve original research studies on stem cell-based tissue engineering treatments tested in preclinical models of burn wounds, published between January 2009 and June 2021. Of the 347 articles retrieved from the initial database search, 33 were eligible for inclusion in this review. The majority of studies used murine models with a xenogeneic graft, while a few used the porcine model. Thermal burn was the most commonly induced injury type, followed by surgical wound, and less commonly radiation burn. Most studies applied stem cell treatment immediately post-burn, with final endpoints ranging from 7 to 90 days. Mesenchymal stromal cells (MSCs) were the most common stem cell type used in the included studies. Stem cells from a variety of sources were used, most commonly from adipose tissue, bone marrow or umbilical cord, in conjunction with an extensive range of biomaterial scaffolds to treat the skin wounds. Overall, the studies showed favourable results of skin wound repair in animal models when stem cell-based tissue engineering treatments were applied, suggesting that such strategies hold promise as an improved therapy for burn wounds.
\end{abstract}

Keywords Tissue engineering $\cdot$ Stem cells $\cdot$ Biomaterials $\cdot$ Burn wounds $\cdot$ Animal models

\section{Introduction}

Alissa Olga Lukomskyj, Nikitha Rao and Lei Yan are equal first authors.

Bin Wang

wangbin_pku@163.com

$\triangle$ Jiao Jiao Li

jiaojiao.li@uts.edu.au

1 Kolling Institute, Faculty of Medicine and Health, University of Sydney, St Leonards, NSW 2065, Australia

2 School of Biomedical Engineering, Faculty of Engineering and IT, University of Technology Sydney, Sydney, NSW 2007, Australia

3 Department of Orthopedics, Shanxi Medical University Second Affiliated Hospital, Taiyuan 030001, China

4 Chemical and Environmental Engineering, School of Engineering, RMIT University, Melbourne, VIC 3000 , Australia

5 Department of Orthopaedic Surgery, The First Affiliated Hospital, Zhejiang University School of Medicine, Hangzhou 315000, China
Skin is the body's largest organ and the first line of defence against injury or infection [1]. Burn wounds are a primary cause of skin damage, which have significant negative impacts on the physical and mental health of patients, leading to reduced quality of life. Burns are considered a global health issue and account for 180,000 deaths annually [2]. In Australia alone, there were 5,430 hospitalisations for burns in $2013-14$, constituting $1.2 \%$ of all injury-related cases during this time period [3]. The average cost of burns treatment for Australian patients is a staggering \$71,056 [3], which may be increased by several fold depending on the severity of the burn. High threat to life cases alone prolong the standard 7 days of hospitalisation to 17 days, evidencing the huge socio-economic burden of burn wounds on both the patient and healthcare facilities [3]. Furthermore, burn wounds lead to poorer quality of life for the patient [4], as they cause a decline in physical functioning and may impact the capacity to work, body image, basic abilities and mental health of patients [5]. The loss of $15 \%$ of the total 
body surface area (TBSA) from burn injury is sufficient to be considered life-threatening [6,7]. Burn wounds are also more complex to manage and treat when they occur in paediatric patients under 5 years, or elderly persons over 60 years of age [7].

The complex structure and function of skin pose numerous challenges in regeneration after burn injury. The skin is composed of three distinct layers: the epidermis, dermis and hypodermis. The epidermis acts as the primary defence layer against organic elements and offers protection from the external environment. Thickness varies depending on the region of the body. The dermis is the second major layer of skin and is composed of collagen, elastin, electrolytes, and water. It also varies in thickness depending on location, ranging from $200 \mu \mathrm{m}$ in the eyelids to $3 \mathrm{~mm}$ in the back. The hypodermis provides insulation from cold and violent trauma, and also acts to store energy [8]. Epidermal appendages consist of hair follicles, sebaceous glands, apocrine glands and eccrine glands [9]. Hair follicles are distributed all over the body except for the palms and soles, providing protection from ultraviolet radiation and preventing foreign material from entering the body. Sebaceous glands are found where hair is present and are responsible for sebum production and secretion to lubricate the skin. Apocrine glands are only found in certain areas of the body and their odourless secretion reacts with bacteria on the skin's surface to produce body odour. Eccrine glands are present all over the skin's surface and aid in retaining moisture and regulating body temperature, through the controlled release of sweat. In burn wounds, the inflicted damage leads to the death of skin cells and leaves the area susceptible to infection. Effective treatments for burn injury must first overcome the huge barrier of vascularisation, as failure to provide an adequate blood supply to the skin can result in necrosis, infection, sloughing or sepsis [6]. Epidermal appendages lost at the site of damage also typically fail to regenerate, leaving behind tissue scars from the poorly reconstituted collagen matrix [10].

Current clinical practices for treating burn wounds include skin grafting, skin substitutes, and negative pressure wound therapy (NPWT). The standard treatment for burn wounds involves early excision of necrotic tissue followed by autologous skin grafting procedures [11]. However, the limited availability of autologous skin becomes an issue for patients with severe burn injuries [12]. This problem can be solved by repeated harvesting of the donor site, but the site must re-epithelialise within 2 to 3 weeks to reduce scarring [13]. Biological skin substitutes including amnion and cultured epithelial autografts (CEA) have proven effective in the treatment of burn wounds, although the presence of allogeneic products presents a risk of contamination and disease transmission [14]. Synthetic skin substitutes such as Biobrane ${ }^{\circledR}$ and Suprathel ${ }^{\circledR}$ have shown favourable results in accelerating healing time and reducing pain, but still pose risks of infection and hypertrophic scarring [15]. For NPWT, a clinical trial involving small-area, thermal paediatric burns showed that this expedited re-epithelialisation [16]. However, NPWT can be problematic for both patients and caregivers due to the physical burden, technical difficulties and mechanical issues. Hence, current clinical approaches are associated with numerous practical drawbacks for the patient, and also lack efficacy in the complete renewal of skin that has been compromised by burn wounds. These limitations call for the need to develop tissue engineered treatment methods.

Tissue engineering approaches have become a significant area of interest for the treatment of burn wounds. Tissue engineered skin replacements have great potential for widespread applications in the field of wound healing, particularly to address the limited availability of autologous skin [17]. Recent advances include the exploration of strategies involving stem cells, biomaterials, and advanced manufacturing methods such as 3D printing to produce effective, alternative treatments. For instance, the role of adipose tissue-derived stem cell (AdSC) transplantation in skin repair has been demonstrated in a murine model [18], where enhanced tissue regeneration was evidenced by increased cell proliferation, a higher degree of neovascularisation, and up-regulation of the epidermal growth factor (EGF) protein. Moreover, a variety of biomaterials have been investigated as scaffolds to support skin regeneration, such as silk fibroin [19], metal-doped calcium silicate [20], and polymeric hydrogel scaffolds [21]. These biomaterials have been shown to favour re-epithelialisation and angiogenesis, reduce the risk of post-injury infection, and possess excellent biocompatibility. Additionally, new methods have been developed to 'print' functional living skin, such as by using a biomimetic bio-ink and digital light processing-based 3D printing technology [22]. This approach was shown to promote efficient neovascularisation by mimicking the structure of natural skin, which induced dermal regeneration in a large animal model. Furthermore, Integra [23], a widely recognised dermal replacement technology worldwide, provides a scaffold for endogenous cell ingrowth and dermal stroma synthesis following healing. Integra has been used clinically as a skin substitute [24], and shown to reduce wound surface area and accelerate healing [25]. However, a major challenge lies in its susceptibility to infection, caused by the collection of haematomas and seromas beneath the artificial skin substitute [26].

Currently, stem cells used for skin tissue engineering are in preclinical testing stages, with experimental studies only starting to emerge from 2010. Stem cells can provide critical benefits to tissue engineered burns treatment by stimulating direct differentiation into skin tissue structures, and interacting with nearby cells to create a 
more inducive environment for regeneration. The therapeutic potential of stem cells arises from their ability to secrete regenerative cytokines, making them an attractive choice for treating chronic wounds [27]. In preclinical treatments of burn wound models, inclusion of stem cells has resulted in better wound healing by inducing improved granulation tissue formation, collagen deposition, healing speed, wound appearance, amount of scarring, presence of adnexal structures, regulation of inflammatory markers, and formation of vascular structures in the epidermal layer as well as its thickness and structure. By far the most popular type of stem cell being used in preclinical studies of burn wound repair are mesenchymal stromal cells (MSCs), commonly harvested from adipose tissue, bone marrow, and umbilical cord. MSCs play an important role in skin homeostasis and damage repair by promoting immune regulation, monitoring resident stem cells, and secreting growth factors to drive epithelialisation and neovascularisation [28, 29]. Other types of adult stem cells have proven to be useful for skin repair, such as those derived from hair follicle, dental pulp, and kidney. Pluripotent stem cells have also been used, but may raise several issues. Embryonic stem cells (ESCs) and foetal stem cells (FSCs) are associated with moral concerns and substantial legal restrictions, slowing down their applications in clinical wound healing [30, 31]. These and induced pluripotent stem cells (iPSCs) are also prone to teratoma formation due to their pluripotency depending on the efficiency of the differentiation protocol, raising potential safety concerns [32]. Hence, ESCs, FSCs and iPSCs have not been included in our analysis due to their current limitations in being used for clinical applications. In vitro studies have also been excluded, since studies involving animal models are more closely representative of the clinical performance of new burns treatment strategies.

The vast majority of studies using a stem cell-based approach for treating burn wounds are at the preclinical testing stage, and vary widely in their methods and outcomes. Over the past three years, only a few reviews have discussed tissue engineering methods for skin repair, with a primary focus on biomaterials [33], murine models [34], pluripotent stem cells [32], or immunomodulation [31] and other signalling pathways [30]. This review will cover the latest advances in tissue engineered solutions involving adult stem cells, tested in a variety of preclinical models. It will inform researchers and clinicians on the current progress in developing an ideal stem cellbased treatment for burn wounds, reflecting on a range of aspects including the type and source of stem cell, type of scaffold/matrix, animal model, graft type, type of wound injury, timeframe of treatment and analysis, and any proposed mechanisms.

\section{Methods}

\section{Literature search strategy}

Selection of studies in this review was performed using the PRISMA scoping review protocol and checklist [35]. A comprehensive search of the electronic databases Embase, Medline, Scopus, and Web of Science was conducted for studies published since 1 January 2009 , on using stem cellbased tissue engineering approaches to treat burn wounds in preclinical animal models. Specific search strategies used for each database are presented in the Supplementary Information.

\section{Inclusion and exclusion criteria}

The inclusion criteria for this review were peer-reviewed original research articles sourced from online databases, published between January 2009 and June 2021, in English language. The studies (1) must have tested a stem cell-based tissue engineering product, defined as a functional construct containing a specifically defined stem cell type and a supporting matrix or scaffold, (2) the purpose of the product must have been for skin regeneration or wound healing, (3) the product must have been used on a burn wound or the authors must have stated that it could be used to treat burns, and (4) the product must have been tested on an animal skin wound model.

The exclusion criteria were non-original research articles, articles published before 2009 or not in English language, and research where full text was not available including conference abstracts. Studies were also excluded if they (1) did not test a tissue engineered wound dressing or skin substitute (for example, placing stem cells directly onto a wound, or injecting stem cells into a wound), (2) did not incorporate a specifically defined type of adult stem cell (for example, precursor cells, progenitor cells, keratinocytes, stem cell-like cells, colony-forming units, ESCs, FSCs, iPSCs, growth factors, cytokines, or tissues that were said to contain stem cells without properly isolating and classifying them), (3) did not use the product for skin regeneration or state that it could be used for this purpose, (4) did not apply the product to burns or state that it could be used for this purpose, and (5) did not test the product in an animal skin wound model.

\section{Study screening and reporting}

The screening process followed a structure set out in the PRISMA flow chart [36]. The records of retrieved studies were imported into Endnote X8 for study screening. Title and abstract screening were performed, followed by full-text screening using the inclusion and exclusion criteria. Studies where the full text was not accessible were excluded. 
Data items extracted from articles included animal model, source of stem cell, type of stem cell, type of graft, skin wound model, timeframe of treatment, length of follow-up, type of scaffold/matrix, summary of findings, and proposed mechanisms.

\section{Results}

There were 697 potential studies identified from database searches. After removing duplicates, 349 studies were screened based on title and abstract. From these, 150 studies were included for full text screening, after removing articles that were not relevant to topic of this review, or were not original research articles. Of the 150 studies assessed by full text screening, 33 were eligible for inclusion in this review. The 117 that were excluded did not comply with the inclusion and exclusion criteria: 3 were unable to be obtained as full text articles, 11 were not original research studies, 18 were not tested on an animal model, 55 did not use a defined source of adult stem cells, 2 did not incorporate stem cells into the tissue engineered product, 26 did not test a tissue engineered product or wound dressing, and 2 did not test the product on a burn wound model or specifically state a potential use in burns. The study selection process is outlined in Fig. 1.

\section{Main findings}

A summary of the included studies is presented in Table 1, depicting the animal model, skin wound model, treatment timeframe, final endpoint, type of graft, type and source of stem cells used, type of scaffold/matrix, summary of findings, and proposed mechanisms. Where specified, a summary of results from the included studies on the time period for wound recovery (defined as when granulation tissue has begun to fill the wound), thickness of neo-skin formed in the treatment group(s), and incidence and nature of complications is presented in Table 2 .

The sources of stem cells, wound model, and type of graft used in the included studies are shown in Fig. 2. Among the 33 studies, 17 used rats, 13 used mice, and 3 used a porcine model. Studies using a mouse model included the widest variety of stem cell sources. MSCs were the most commonly used stem cell type among the included studies, which were often derived from adipose tissue, umbilical cord, or bone marrow. The most common type of graft applied across all animal models was a xenograft, consisting of a product containing stem cells derived from an animal of a different species from the graft recipient. The most common wound model used across all animal models was thermal burn, which was the most popular choice in rat and porcine studies, although surgical wound was more popular among mouse studies.

The number of days in treatment delay after wound model creation, and in assessing the end point after applying stem cell-based treatment for the included studies are shown in Fig. 3. All studies using a surgical wound model applied treatment immediately after inflicting the injury, while studies using thermal and radiation wounds varied in the number of days between wound creation and treatment,
Fig. 1 Flow chart for the study selection process



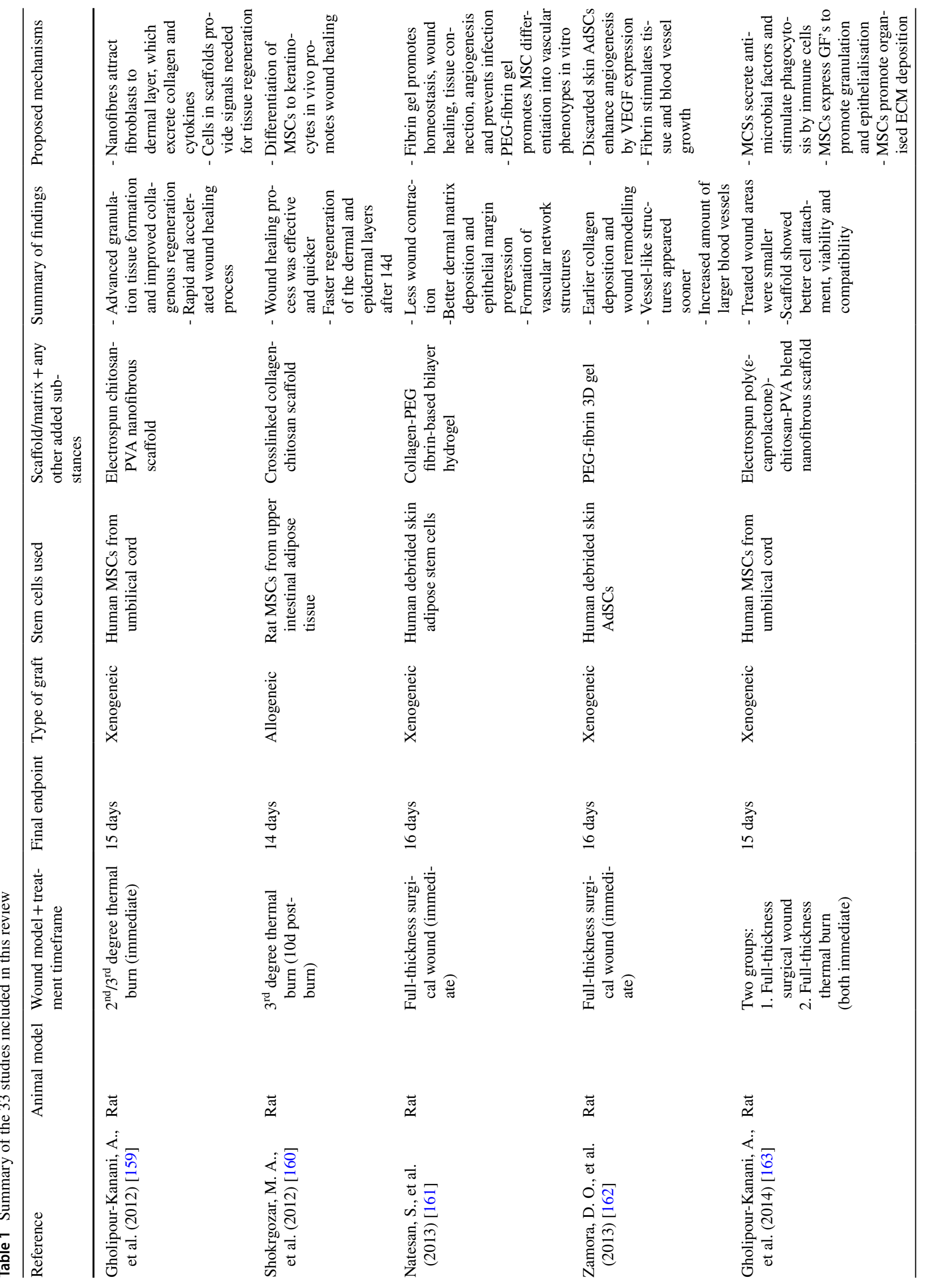




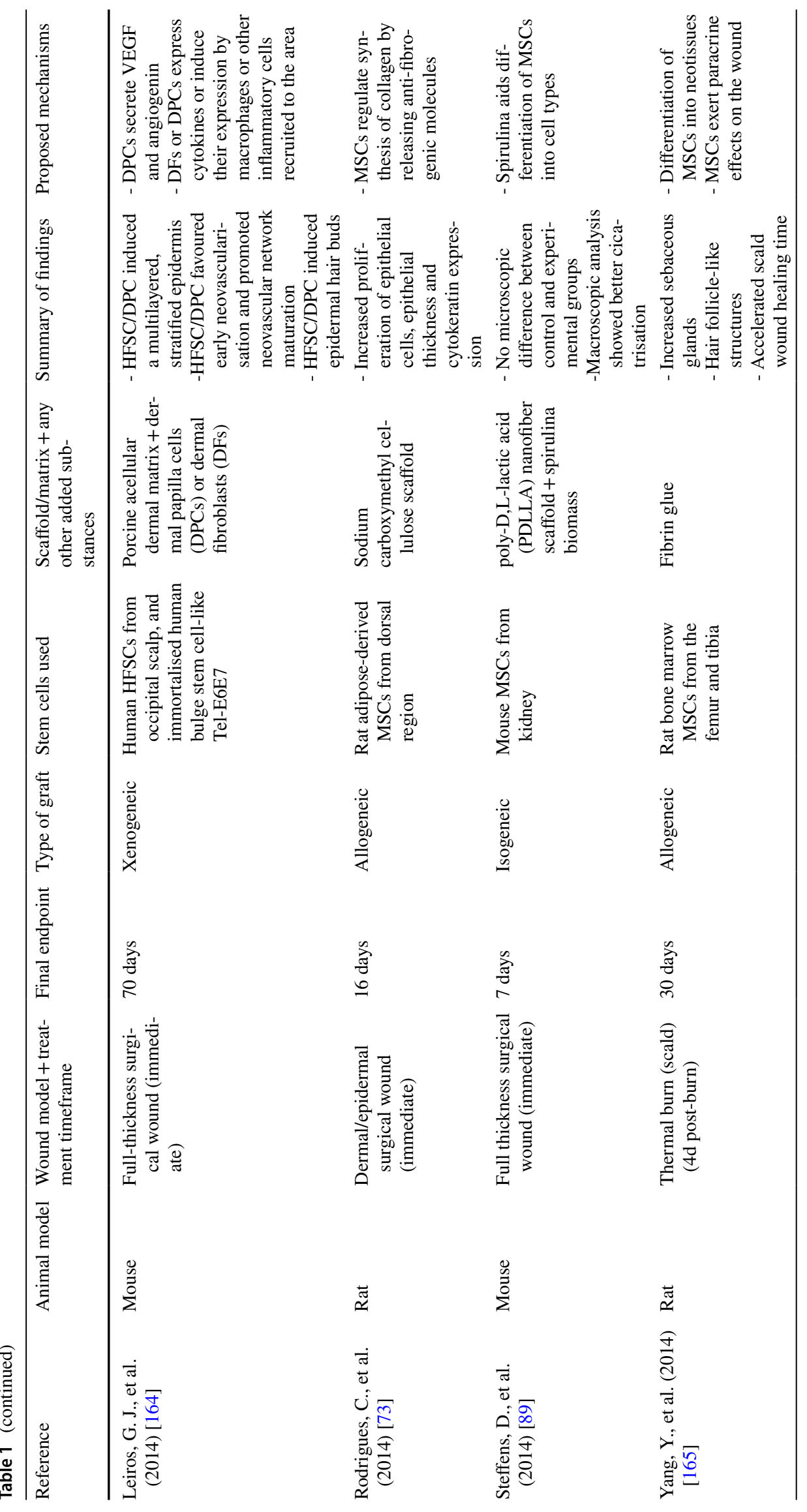




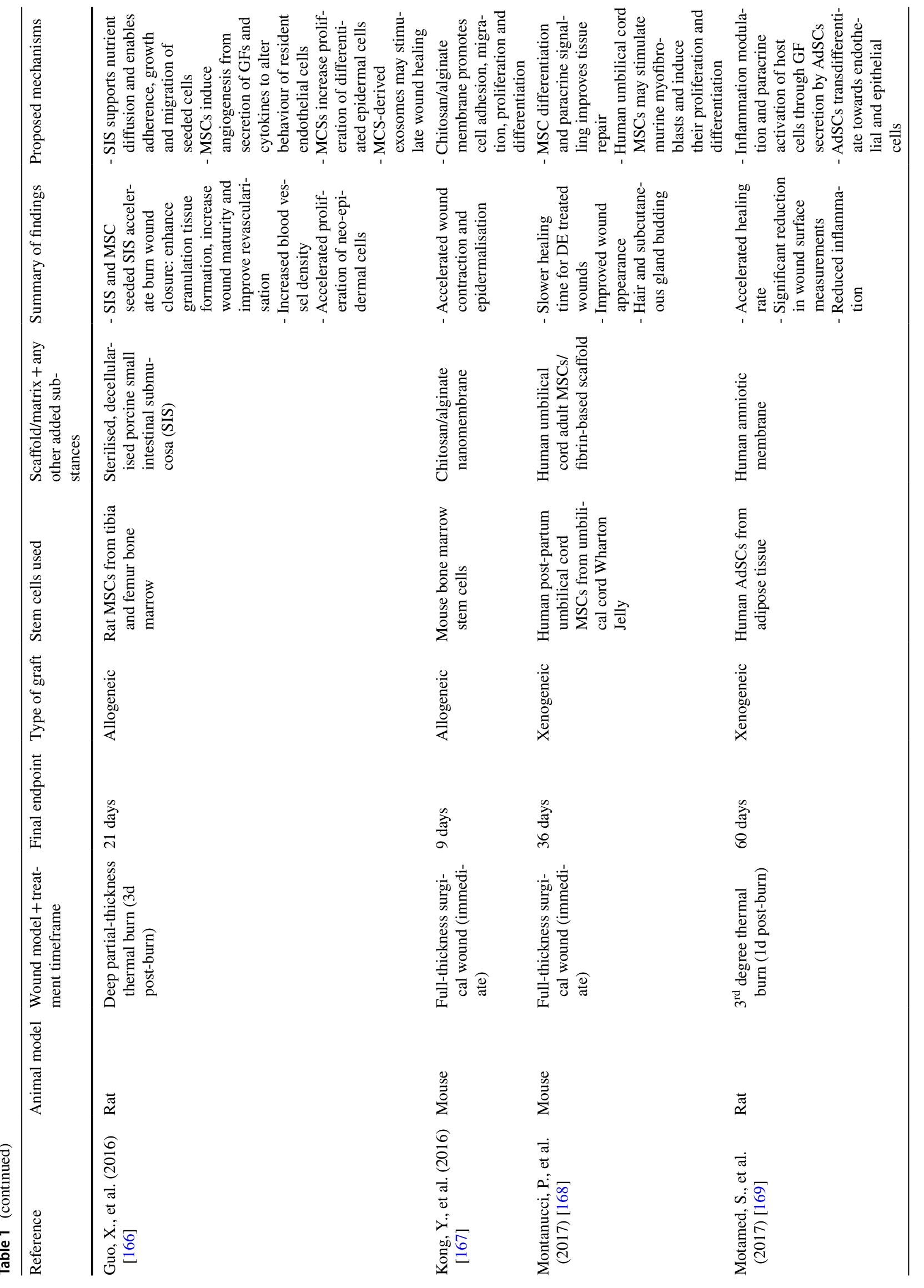




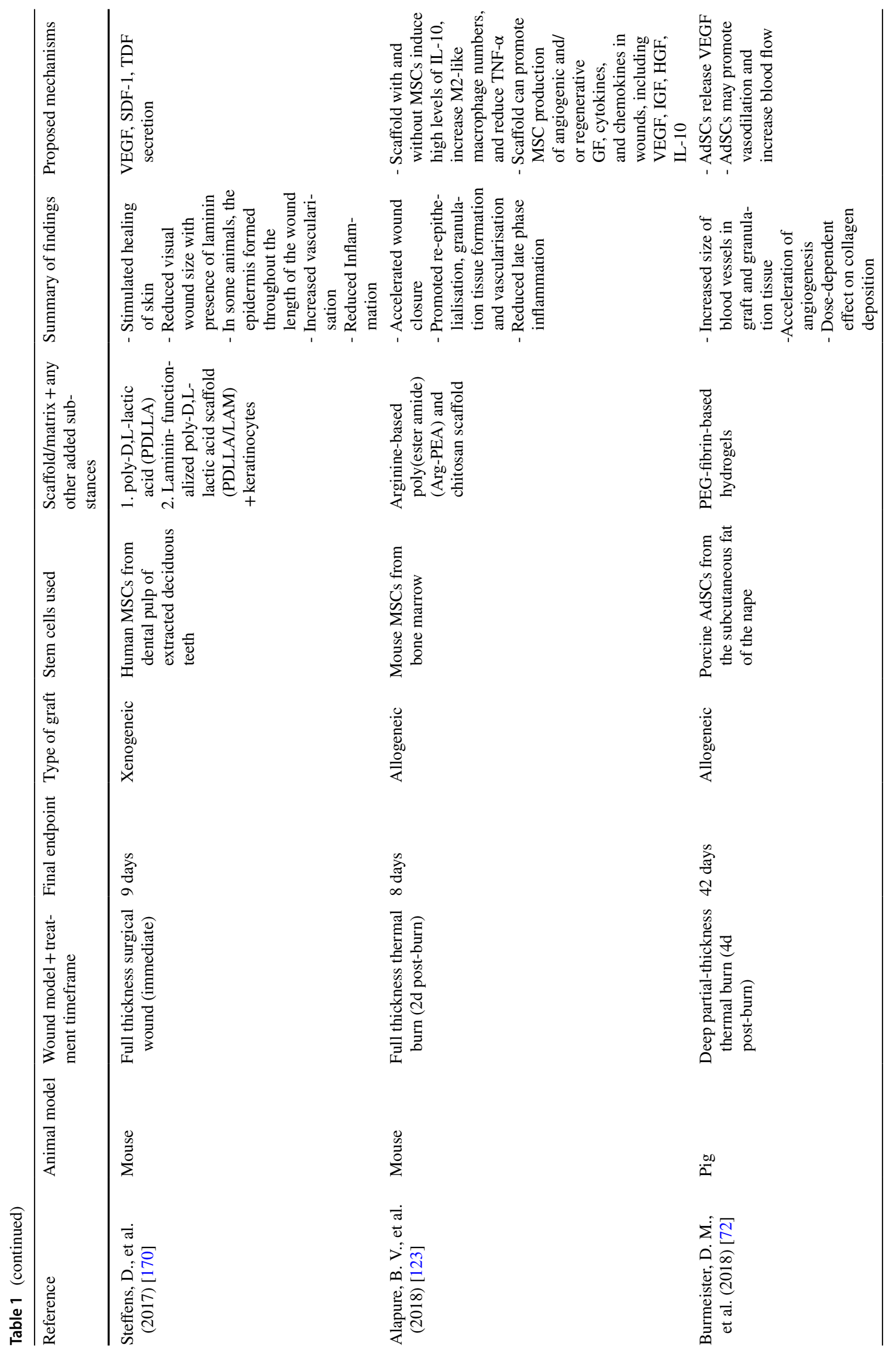




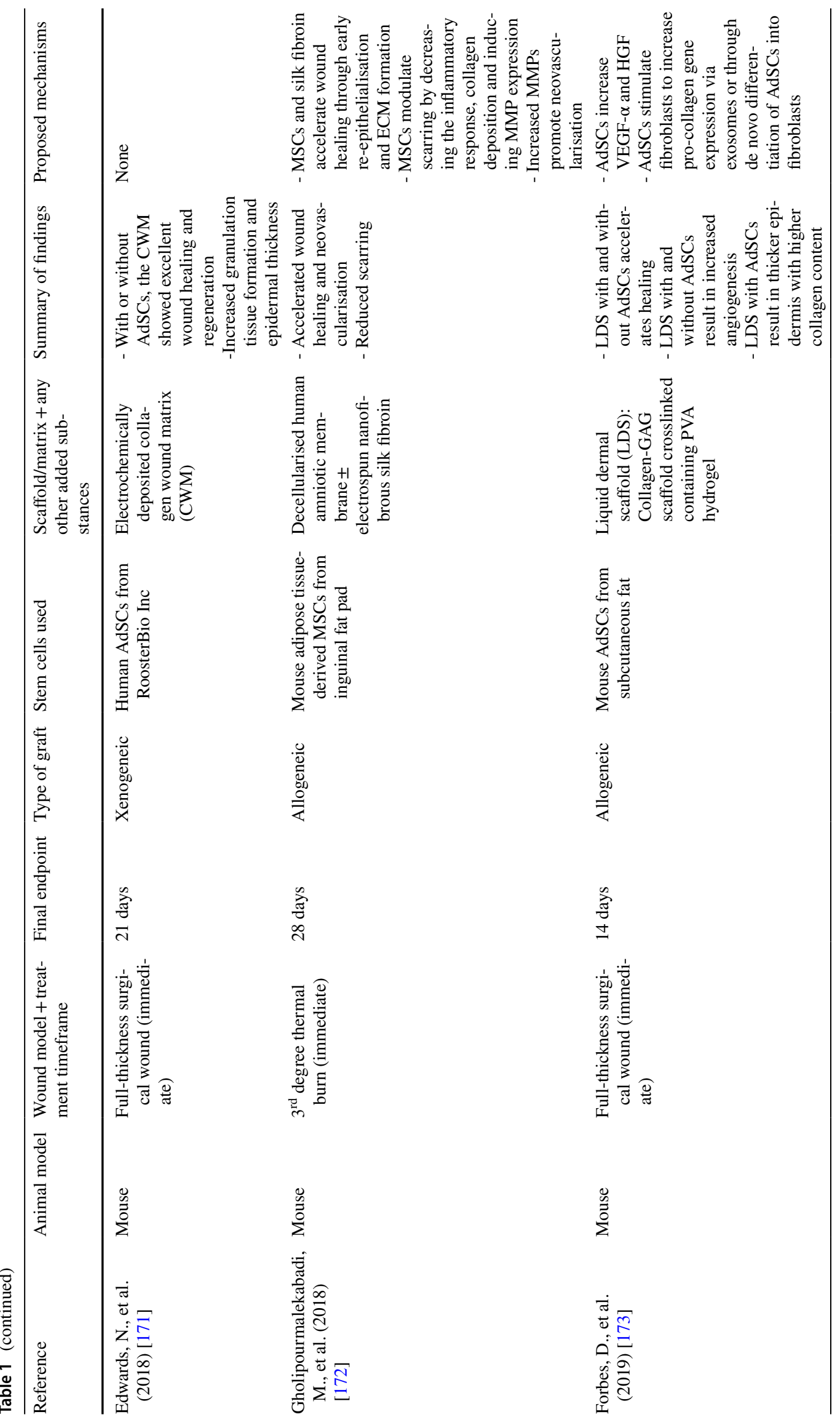




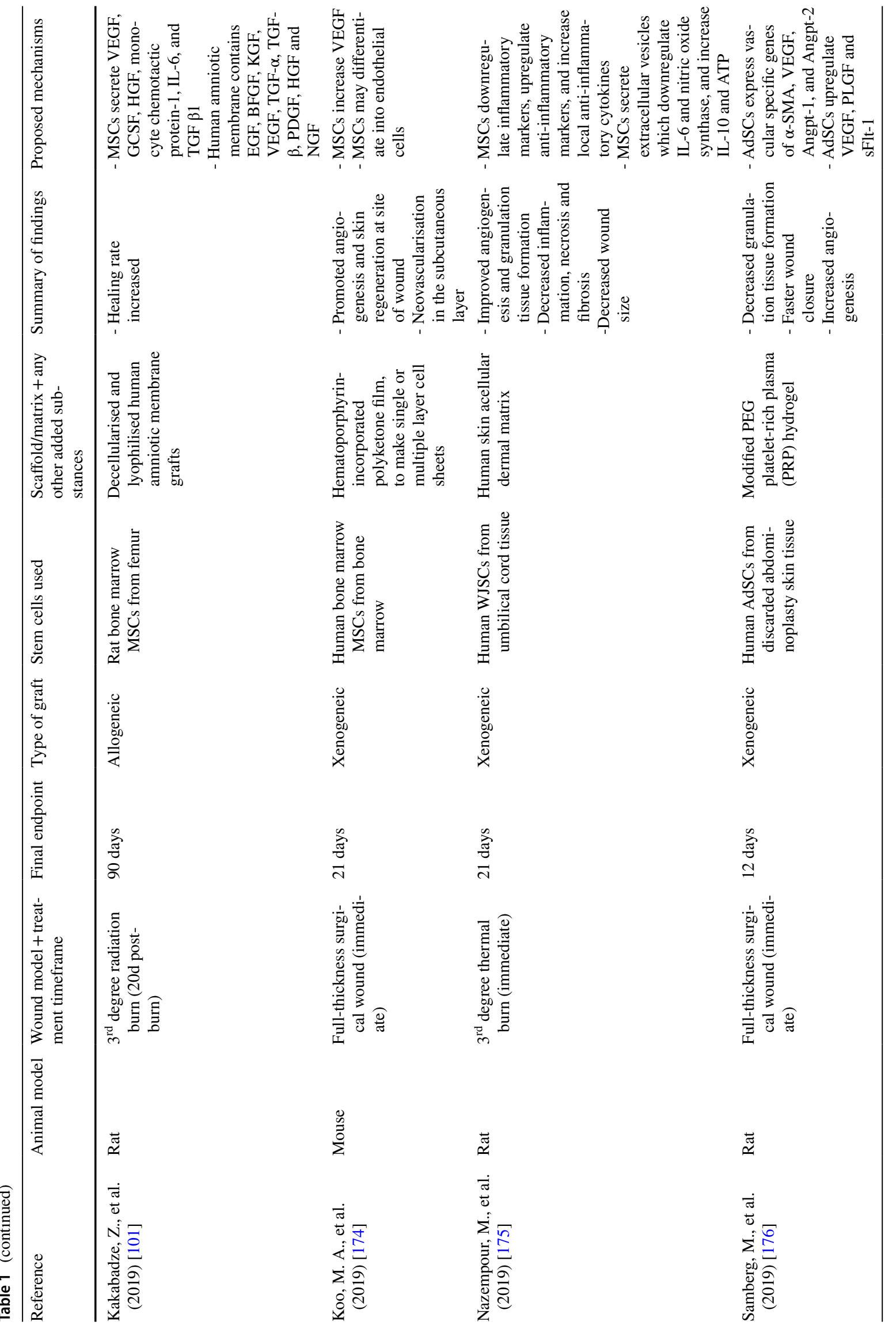




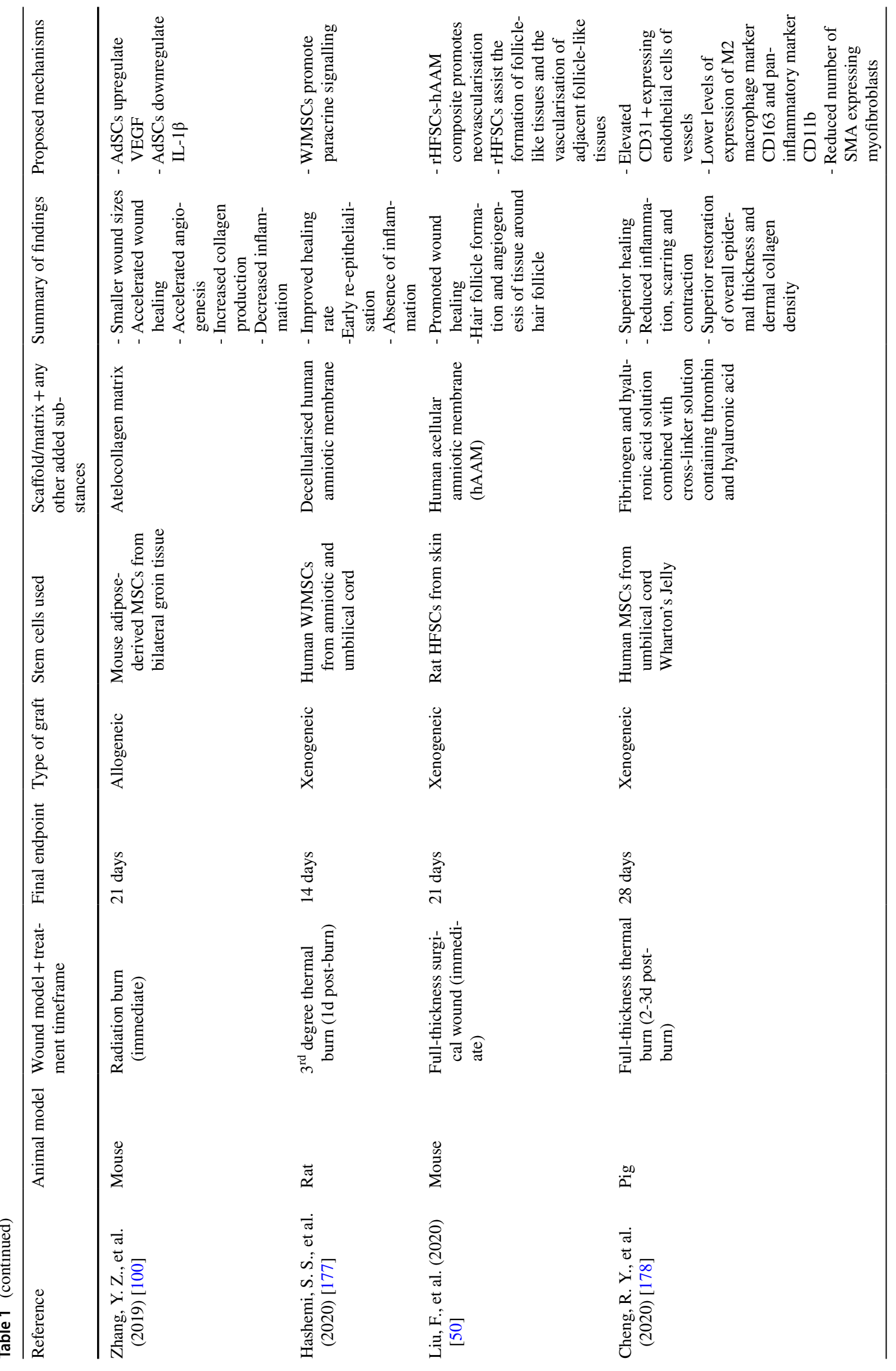




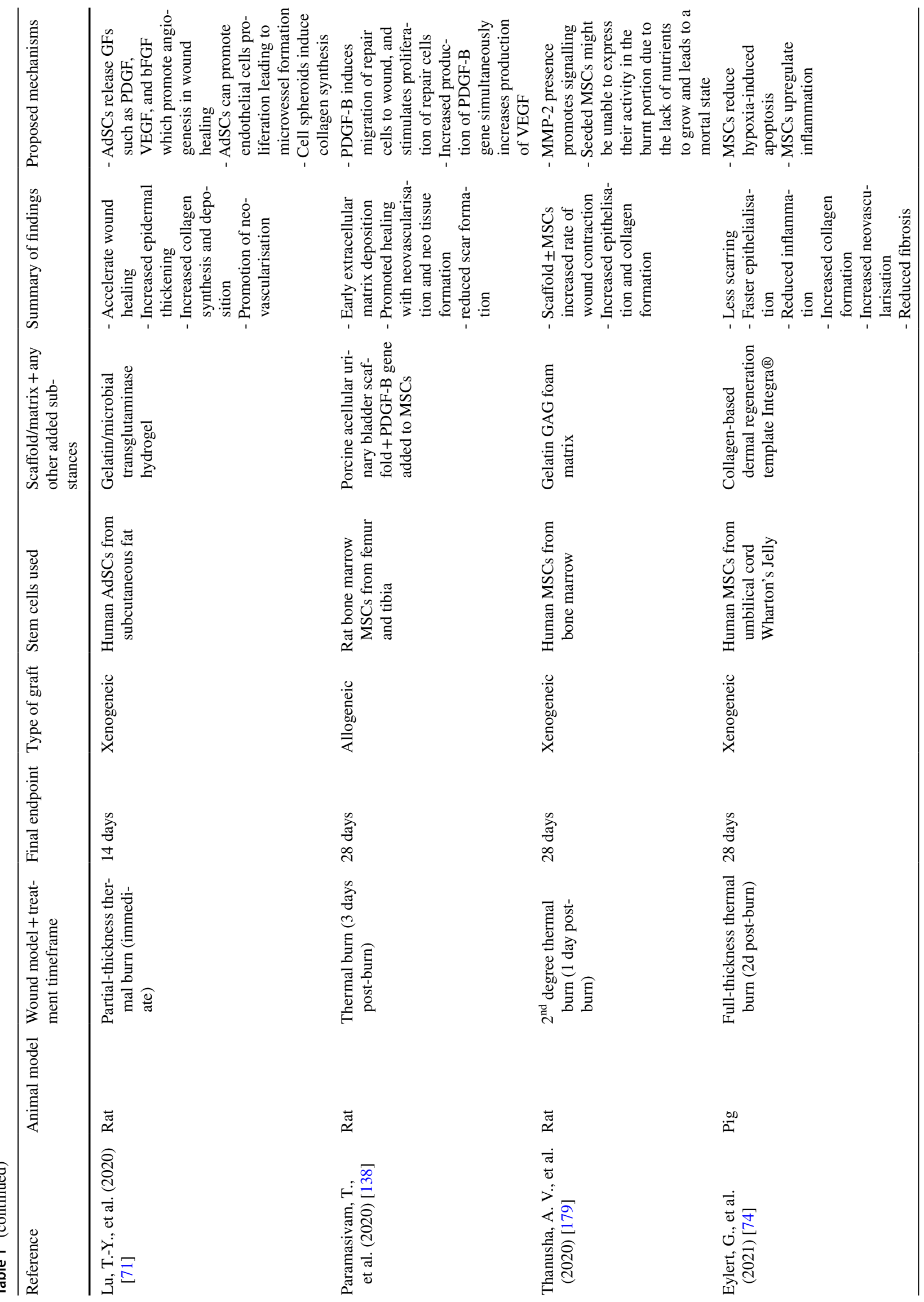




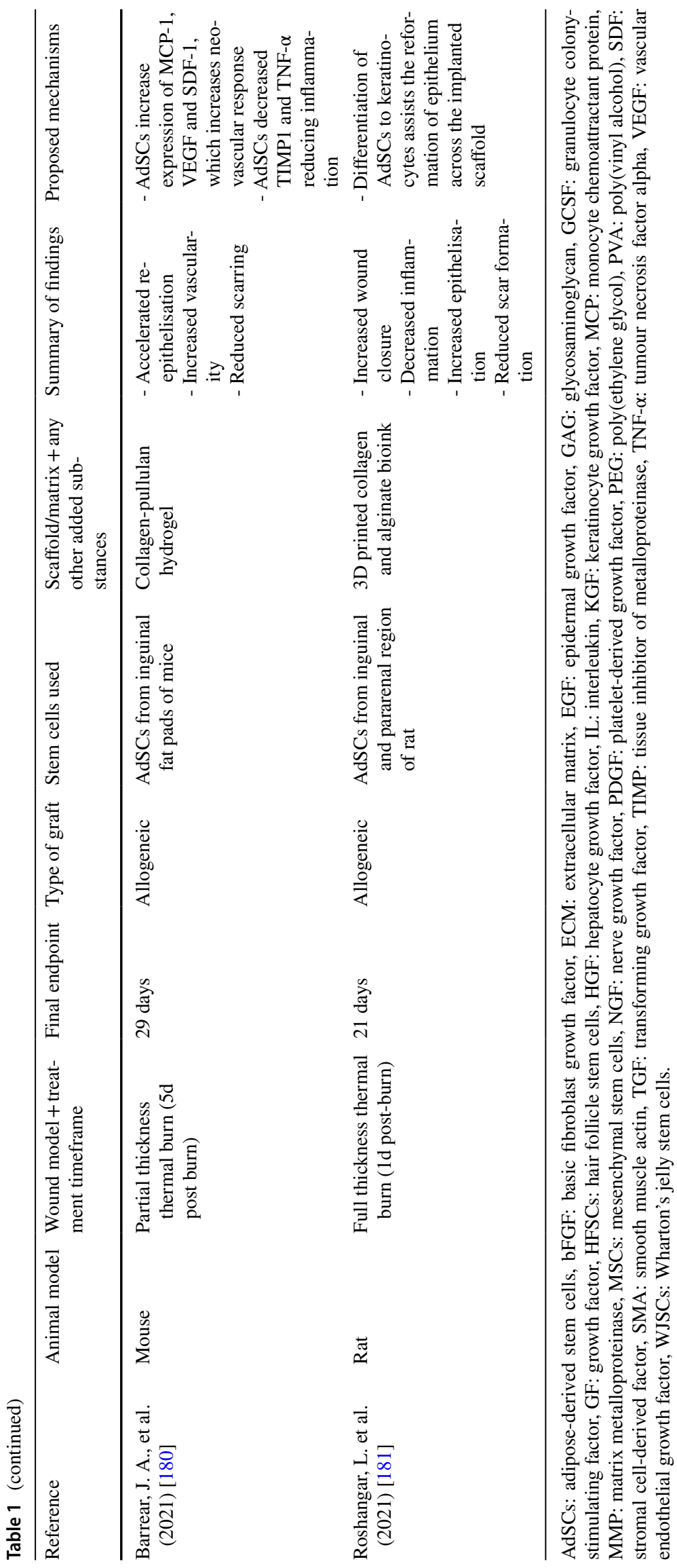


Table 2 Summary of results from the included studies on time period for wound recovery (defined as when granulation tissue has begun to fill the wound), thickness of neo-skin, and incidence and nature of complications (unspecified data indicated by -)

\begin{tabular}{|c|c|c|c|c|c|}
\hline \multirow[t]{2}{*}{ Reference } & \multirow[t]{2}{*}{ Animal model } & \multirow{2}{*}{$\begin{array}{l}\text { Time period for start of } \\
\text { wound recovery (days) }\end{array}$} & \multirow{2}{*}{$\begin{array}{l}\text { Thickness of neo-skin in } \\
\text { treatment group(s) }\end{array}$} & \multicolumn{2}{|c|}{ Complications } \\
\hline & & & & $\begin{array}{l}\text { Number } \\
\text { of ani- } \\
\text { mals }\end{array}$ & $\begin{array}{l}\text { Nature of complications \& } \\
\text { group(s) affected }\end{array}$ \\
\hline $\begin{array}{l}\text { Gholipour-Kanani, A., et al. } \\
\text { (2012) [159] }\end{array}$ & Rat & 10 & - & - & - \\
\hline $\begin{array}{l}\text { Shokrgozar, M. A., et al. } \\
\text { (2012) [160] }\end{array}$ & Rat & 14 & - & - & - \\
\hline $\begin{array}{l}\text { Natesan, S., et al. (2013) } \\
\text { [161] }\end{array}$ & Rat & 8 & - & - & - \\
\hline $\begin{array}{l}\text { Zamora, D. O., et al. (2013) } \\
\text { [162] }\end{array}$ & Rat & 8 & - & 2 & $\begin{array}{l}\text { Inflammation, infection, red- } \\
\text { ness (but no mortality): } \\
\text { Saline control group only }\end{array}$ \\
\hline $\begin{array}{l}\text { Gholipour-Kanani, A., et al. } \\
\text { (2014) [163] }\end{array}$ & Rat & 10 & - & - & - \\
\hline $\begin{array}{l}\text { Leiros, G. J., et al. (2014) } \\
\text { [164] }\end{array}$ & Mouse & 14 & - & - & - \\
\hline $\begin{array}{l}\text { Rodrigues, C., et al. (2014) } \\
\text { [73] }\end{array}$ & Rat & 8 & - & - & - \\
\hline $\begin{array}{l}\text { Steffens, D., et al. (2014) } \\
\text { [89] }\end{array}$ & Mouse & - & - & 15 & $\begin{array}{l}\text { Ulceration, inflammation, } \\
\text { fibrosis (but no mortality): } \\
\text { All control and treatment } \\
\text { groups }\end{array}$ \\
\hline Yang, Y., et al. (2014) [165] & Rat & 14 & - & - & - \\
\hline Guo, X., et al. (2016) [166] & Rat & 7 & - & - & - \\
\hline Kong, Y., et al. (2016) [167] & Mouse & 7 & $\begin{array}{l}\text { Granulation tissue mean } \\
\text { thickness: } \\
600 \mu \mathrm{m}\end{array}$ & & - \\
\hline $\begin{array}{l}\text { Montanucci, P., et al. (2017) } \\
\text { [168] }\end{array}$ & Mouse & 15 & - & - & - \\
\hline $\begin{array}{l}\text { Motamed, S., et al. (2017) } \\
\text { [169] }\end{array}$ & Rat & 7 & - & 32 & $\begin{array}{l}\text { Dermis showed oedema, } \\
\text { mild to moderate acute } \\
\text { and chronic inflammatory } \\
\text { cell infiltration and fibro- } \\
\text { sis, and partial destruction } \\
\text { of dermal appendages: } \\
\text { All control and treatment } \\
\text { groups }\end{array}$ \\
\hline $\begin{array}{l}\text { Steffens, D., et al. (2017) } \\
\text { [170] }\end{array}$ & Mouse & - & - & - & - \\
\hline $\begin{array}{l}\text { Alapure, B. V., et al. (2018) } \\
\text { [123] }\end{array}$ & Mouse & 8 & - & - & - \\
\hline $\begin{array}{l}\text { Burmeister, D. M., et al. } \\
\text { (2018) [72] }\end{array}$ & Pig & 10 & - & - & - \\
\hline $\begin{array}{l}\text { Edwards, N., et al. (2018) } \\
\text { [171] }\end{array}$ & Mouse & 7 & $\begin{array}{l}\text { Epidermis mean thickness: } \\
60 \mu \mathrm{m}\end{array}$ & - & - \\
\hline $\begin{array}{l}\text { Gholipourmalekabadi, M., } \\
\text { et al. (2018) [172] }\end{array}$ & Mouse & 14 & - & - & - \\
\hline $\begin{array}{l}\text { Forbes, D., et al. (2019) } \\
\text { [173] }\end{array}$ & Mouse & 14 & - & - & - \\
\hline $\begin{array}{l}\text { Kakabadze, Z., et al. (2019) } \\
\text { [101] }\end{array}$ & Rat & 14 & - & 15 & $\begin{array}{l}\text { Oedema and neutrophilic } \\
\text { tissue infiltration: } \\
\text { Untreated injury group only }\end{array}$ \\
\hline
\end{tabular}


Table 2 (continued)

\begin{tabular}{|c|c|c|c|c|c|}
\hline \multirow[t]{2}{*}{ Reference } & \multirow[t]{2}{*}{ Animal model } & \multirow{2}{*}{$\begin{array}{l}\text { Time period for start of } \\
\text { wound recovery (days) }\end{array}$} & \multirow{2}{*}{$\begin{array}{l}\text { Thickness of neo-skin in } \\
\text { treatment group(s) }\end{array}$} & \multicolumn{2}{|c|}{ Complications } \\
\hline & & & & $\begin{array}{l}\text { Number } \\
\text { of ani- } \\
\text { mals }\end{array}$ & $\begin{array}{l}\text { Nature of complications \& } \\
\text { group(s) affected }\end{array}$ \\
\hline $\begin{array}{l}\text { Koo, M. A., et al. (2019) } \\
\text { [174] }\end{array}$ & Mouse & 14 & $\begin{array}{l}\text { Epidermis/dermis mean } \\
\text { thickness: } \\
80 / 590 \mu \mathrm{m} \text { (cell suspension), } \\
50 / 280 \mu \mathrm{m} \text { (1 layer cell } \\
\text { sheet), 30/230 } \mu \mathrm{m} \text { ( } 3 \text { layer } \\
\text { cell sheet) }\end{array}$ & - & - \\
\hline $\begin{array}{l}\text { Nazempour, M., et al. (2019) } \\
\text { [175] }\end{array}$ & Rat & 21 & - & - & - \\
\hline $\begin{array}{l}\text { Samberg, M., et al. (2019) } \\
\text { [176] }\end{array}$ & Rat & 8 & - & - & - \\
\hline $\begin{array}{l}\text { Zhang, Y. Z., et al. (2019) } \\
\text { [100] }\end{array}$ & Mouse & 7 & - & - & - \\
\hline $\begin{array}{l}\text { Hashemi, S. S., et al. (2020) } \\
\text { [177] }\end{array}$ & Rat & 7 & - & 32 & $\begin{array}{l}\text { Mild to moderate haemor- } \\
\text { rhaging: } \\
\text { All control and treatment } \\
\text { groups } \\
\text { Mild inflammation: } \\
\text { Scaffold alone group }\end{array}$ \\
\hline Liu, F., et al. (2020) [50] & Mouse & 7 & - & - & - \\
\hline $\begin{array}{l}\text { Cheng, R. Y., et al. (2020) } \\
\text { [178] }\end{array}$ & Pig & - & - & - & - \\
\hline Lu, T.-Y., et al. (2020) [71] & Rat & 14 & - & - & - \\
\hline $\begin{array}{l}\text { Paramasivam, T., et al. } \\
\text { (2020) [138] }\end{array}$ & Rat & 7 & - & - & - \\
\hline $\begin{array}{l}\text { Thanusha, A. V., et al. } \\
\text { (2020) [179] }\end{array}$ & Rat & 14 & - & - & - \\
\hline Eylert, G., et al. (2021) [74] & Pig & 28 & $\begin{array}{l}\text { Epidermis median thickness: } \\
189 \mu \mathrm{m}\left(40,000 \text { cells } / \mathrm{cm}^{2}\right) \text {, } \\
157 \mu \mathrm{m}(200,000 \text { cells } / \\
\left.\mathrm{cm}^{2}\right), 131 \mu \mathrm{m}(400,000 \\
\left.\text { cells } / \mathrm{cm}^{2}\right)\end{array}$ & - & - \\
\hline $\begin{array}{l}\text { Barrear, J. A., et al. (2021) } \\
\text { [180] }\end{array}$ & Mouse & 10 & - & - & - \\
\hline $\begin{array}{l}\text { Roshangar, L. et al. (2021) } \\
\text { [181] }\end{array}$ & Rat & 21 & - & - & - \\
\hline
\end{tabular}

with the longest delay being 20 days for a radiation burn wound. The included studies varied in the end time point of analysis, with many having multiple time at which data was collected. In small animals (rats and mice), the final endpoints ranged between 7 to 90 days after treatment, while in large animals (pigs) longer follow-up periods were generally used, with endpoints ranging from 28 to 42 days.

A wide variety of scaffolds and matrices were used to aid stem cell treatment in the included preclinical studies, as shown in Table 3. The biomaterials used included a wide range of natural, synthetic, and commercial materials. A number of studies also included additional substances such as other cell types or bioactive factors along with the scaffolds.

\section{Discussion}

Burn wounds can have severe impacts on quality of life, and current clinical treatments still face many challenges in restoring skin that is anatomically and functionally similar to native tissue, particularly for complex scenarios such as full-thickness or large area burns. Tissue engineering strategies incorporating stem cells have recently opened new doors for the effective treatment of burn wounds. Studies in preclinical models over the last 10 years, captured in this review, demonstrate substantial progress and highlight the prospect of stem cell-based tissue engineered skin constructs becoming a reality in the treatment of clinical burn injuries. In this section, we offer critical insights into different aspects of information reflected in 


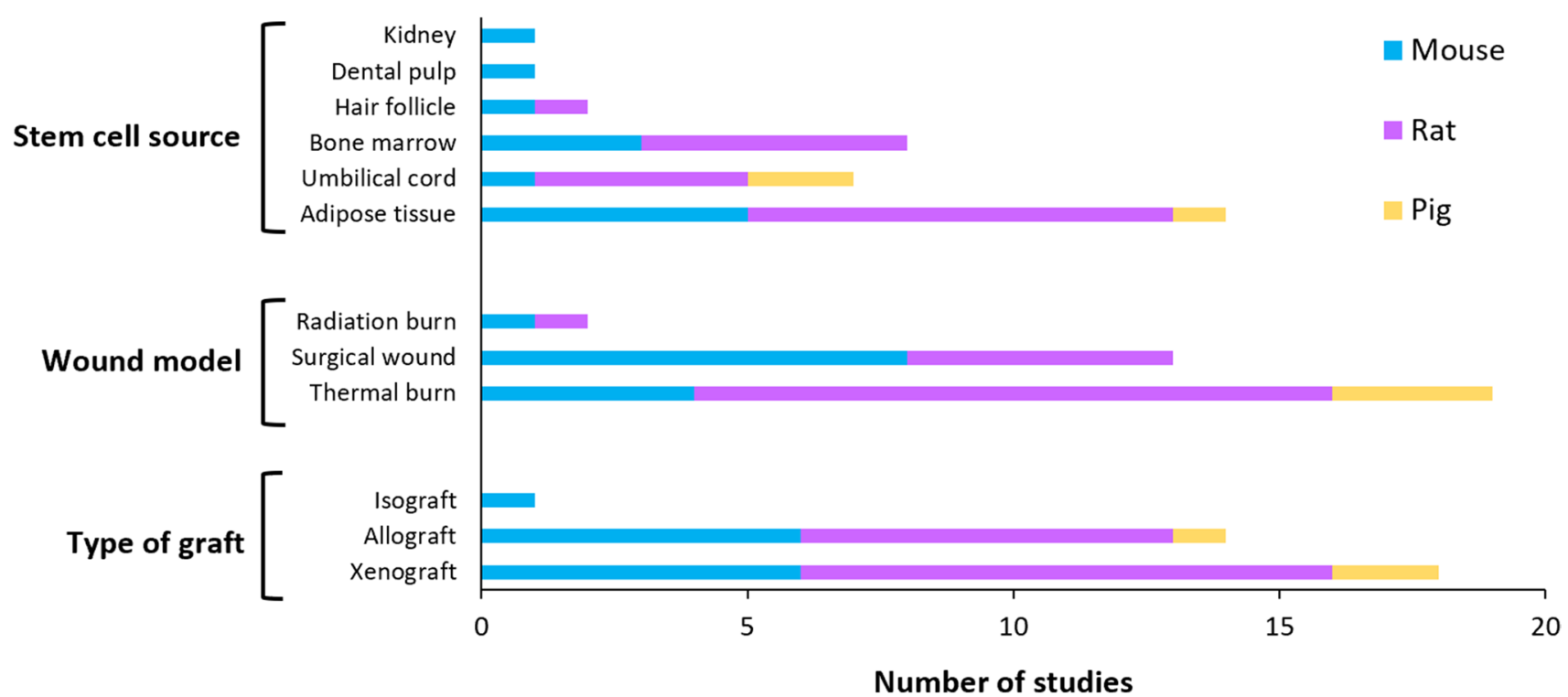

Fig. 2 Sources of stem cells, wound model, and type of graft used in the included studies, further categorised by the frequency by which they were applied in different animal species (mouse, rat and pig)

Fig. 3 The number of days in treatment delay after wound model creation, and in assessing the end point after applying treatment for the included studies. $* \mathrm{p}<0.05, * * \mathrm{p}<0.005$ $\mathrm{ns}=$ not significant

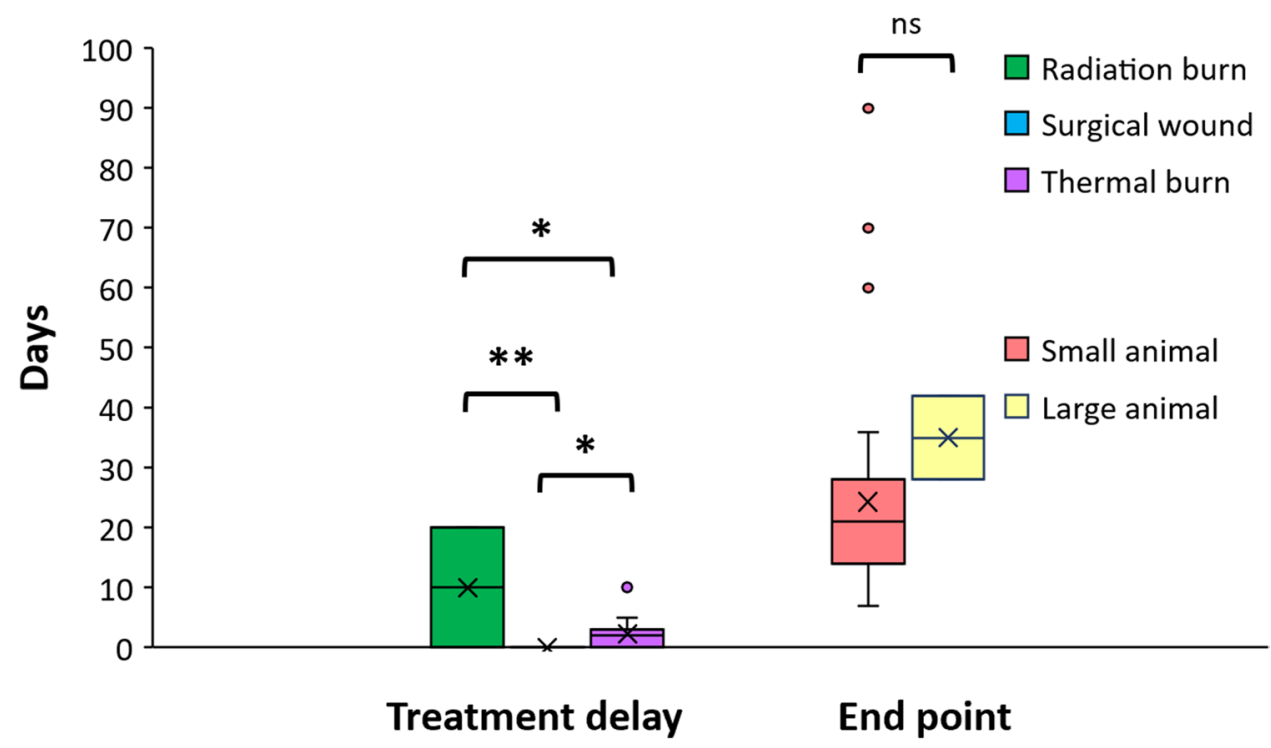

the included studies, providing the latest updates in this exciting field of research.

\section{Animal models}

In our analysis, rats were the most commonly used animal model for burn wound treatment, followed very closely by mice. The primary advantages for using rats in burns studies are their availability and cost-effectiveness [37]. Rats also share several physiological similarities with humans, the most relevant being that rat skin is composed of the dermis and epidermis [38]. However, the primary wound healing method in rats is wound contraction, instead of reepithelisation in humans [37]. The reduced healing time in rats allows researchers to study wound healing mechanisms more rapidly and efficiently. However, rapid healing times and even spontaneous healing can also prevent the risk of sepsis or immunosuppression that are generally seen in larger animal models, reducing the relevance of rats as a model for predicting the outcome of clinical burn wound treatment. Likewise, although mouse models mimic many aspects of human responses to burn injury, there are substantial differences that need to be considered [39]. Dermal and epidermal thickness, scar formation and glucose metabolism 
Table 3 Types of scaffold materials and other substances used in the included studies delivered together with stem cells

\begin{tabular}{|c|c|c|c|}
\hline Natural & Synthetic & Commercial & Additional substances \\
\hline $\begin{array}{l}\text { Acellular amniotic membrane }[50,101,169,172,177] \\
\text { Acellular dermal matrix }[164,175] \\
\text { Alginate }[167,181] \\
\text { Atelocollagen }[100] \\
\text { Chitosan }[123,159,160,163,167,181] \\
\text { Collagen }[160,161,171,173][180] \\
\text { Decellularised bladder }[138] \\
\text { Decellularised small intestine submucosa [166] } \\
\text { Fibrin [72, 161, 162, 165, 168] } \\
\text { Fibrinogen [178] } \\
\text { Gelatin [71] } \\
\text { Glycosaminoglycan }[173,179] \\
\text { Hyaluronic acid [178] } \\
\text { Platelet-rich plasma [176] } \\
\text { Silk fibroin [172] } \\
\text { Sodium carboxymethyl cellulose [73] } \\
\text { Thrombin [178] }\end{array}$ & $\begin{array}{l}\text { Arginine-based polyester amide [123] } \\
\text { Polycaprolactone }[163] \\
\text { Poly-D,L-lactic acid }[89,170] \\
\text { Polyethylene glycol }[72,161,162,176] \\
\text { Polyketone }[174] \\
\text { Polyvinyl alcohol }[159,163,173]\end{array}$ & Integra ${ }^{\circledR}[74]$ & $\begin{array}{l}\text { Dermal fibroblasts [164] } \\
\text { Dermal papilla cells [164] } \\
\text { Hematoporphyrin [174] } \\
\text { Keratinocytes [170] } \\
\text { PDGF-B gene [138] } \\
\text { Spirulina biomass [89] }\end{array}$ \\
\hline
\end{tabular}

post-burn injury differ greatly between mice and humans. Thus, although small animal models confer economic advantages, have rapid reproduction rates, and reduce the time required for study, they have limited translational relevance to humans.

Three of the included studies used pigs as a burn wound model, which have great anatomical and physiological similarity to humans, including in skin structure and response to therapeutics, dermal physiology, transdermal toxicology, wound healing, and neurophysiology [40]. Both humans and pigs have a thick epidermis, 50-120 $\mu \mathrm{m}$ in humans and $30-140 \mu \mathrm{m}$ in pigs [40, 41]. In contrast to small and looseskinned animals such as rodents, pigs and humans do not possess a panniculus carnosus, meaning that both species have a similar distribution of skin blood vessels. Both species also have sparse body hair, which is important since hair follicles impact the process of re-epithelisation. Due to the larger size of pigs, multiple treatments can be compared within the same animal, which reduces inter-individual variability [42]. However, this is not applicable for treatments which induce systemic effects. While porcine models are an optimal choice from a physiological perspective, they have higher costs and special housing requirements, as well as increased ethical concerns over their use [43].

\section{Source of stem cells}

Stem cells used in the included studies were harvested from a variety of sources including adipose tissue, bone marrow, umbilical cord, hair follicle, and dental pulp. These sources differed with respect to their ease of access and feasibility of use in treating burn wounds.

Conventional bone marrow-derived MSCs (BM-MSCs) have limited availability compared to some other sources such as adipose tissue, but treatments utilising BM-MSCs show potential to enhance skin regeneration, for example, by allowing the formation of a thicker epidermal layer and increased cell proliferation, collagen synthesis, and angiogenesis [44]. When obtaining BM-MSCs, aspiration volume directly correlates with cellular yield. Lower aspiration volumes of 10 and $20 \mathrm{~mL}$ have been shown to contain a lower concentration of nucleated cells and yield a lower number of MSCs [45]. In comparison, adipose tissue has been considered a more attractive source for harvesting stem cells, since subcutaneous adipose tissue can be easily accessed and repeatedly sampled, and the enzyme-based isolation procedures are not complicated [46]. The greatest advantage is the high quantity of cells that can be isolated, for instance, it is possible to obtain up to 3.5 million AdSCs from $1 \mathrm{~g}$ of adipose tissue [47]. However, although using liposuction as a standard procedure to collect adipose tissue is relatively safe and has minimal discomfort for the patient, this harvesting method may negatively affect the amount and viability of isolated AdSCs. The umbilical cord presents a reliable, accessible, and non-controversial source of stem cells. Applying umbilical cord-derived stem cells in burn wound models has been found to thicken the epidermis, increase the amount of dermal ridges, and create a better alignment of collagen fibres, demonstrating their active participation in skin wound healing through regenerative processes [48]. A novel method of isolating these stem cells involves cryopreserving cells from fresh umbilical cord post-delivery, in autologous cord plasma, to effectively reduce the risk of prion or virus contamination [49]. However, unlike for bone marrow and adipose tissue, ready access to umbilical cord as a stem cell source is more limited. While these are the predominant sources of stem cells considered for 
treating burn wounds, less utilised sources such as hair follicles and dental pulp also have useful attributes.

Hair follicle stem cells (HSFCs) are involved in the formation of new hair follicles, epithelisation of wounds, and promotion of vascularisation in newly formed skin [50]. Although their original purpose is hair regeneration in response to skin injury, HFSCs are recruited at the site of a burn injury to differentiate into cells that assist in repairing the damaged epithelium [51]. Regulatory T-cells (Tregs) modulating localised inflammation help to promote HFSC differentiation, thereby contributing to skin-barrier regeneration. HFSCs also have multiple advantages including their abundant source, easy sampling and low tissue damage during the sampling procedure, high proliferative capacity and differentiation potential, and the blatant lack of ethical issues [50]. On the other hand, dental pulp stem cells (DPSCs) have potential as a stem cell source as they have been shown to generate mineralised tissue and extracellular matrix in xenograft models [52]. Current isolation methods for DPSCs include the explant method and the enzymatic digestion of pulp tissue method, but these techniques still need to be improved to achieve optimal proliferative capacity of cells, karyotypic stability, and clinal translatability. DPSCs can be implanted in chitosan, collagen or composite biomaterial scaffolds to induce tissue regeneration, and have shown positive results in regenerating periodontal tissue and skin lesions caused by burns. Their regenerative capacity in a burn wound repair model has been suggested to match stem cells derived from bone marrow and adipose tissue [53].

\section{Type of stem cells used and mechanisms of action}

MSCs were the most common type of stem cells used in the included studies. They are a heterogeneous population that commonly refer to adult stem cells capable of differentiating into connective tissues including bone, muscle, cartilage, and fat [54]. MSCs are a popular choice for use in skin tissue regeneration due to a range of beneficial properties, and were the most commonly chosen stem cell type among the included studies in this review. They can be harvested from a wide variety of tissues such as bone marrow, adipose tissue, umbilical cord, and even menstrual blood. The main beneficial functions of MSCs in the context of skin repair include anti-inflammatory and immune-modulation effects [55-57], angiogenesis [58], and promotion of cell proliferation [59].

MSCs are known to migrate to wound sites, differentiate, and regenerate lost tissue by regulating cellular responses to injury through paracrine signalling [60]. Experimental studies have shown that MSCs can coordinate inflammatory responses following tissue injury. For instance, MSCs secrete multiple inflammatory modulators including nitric oxide (NO), indoleamine 2,3-dioxygenase (IDO), prostaglandin E2 (PGE2), interleukin(IL)-10 and
TNF-alpha-stimulated gene/protein 6 (TSG-6) [61]. MSCs can also facilitate wound healing by increasing the secretion of anti-inflammatory cytokines such as IL-10, which results in reduced levels of inflammatory IL-6 and IL-8, as well as decreased collagen production and hence reduced fibrosis [62]. Other beneficial interactions of MSCs include promoting the production of anti-inflammatory IL-35, PGE2 which reduces natural killer cell proliferation and T-cell migration, vascular endothelial growth factor (VEGF) which promotes angiogenesis, and hepatocyte growth factor (HGF) which is involved in downregulating fibrosis and increasing cell recruitment in the wound bed [62]. MSCs can also influence wound healing by decreasing the levels of pro-inflammatory cytokines including tumour necrosis factor (TNF)- $\alpha$ and interferon (IFN)- $\gamma$ [63]. In the remodelling phase of wound healing, MSCs produce transforming growth factor (TGF)- $\beta 3$ and keratinocyte growth factor (KGF), as well as regulate the activity of matrix metalloproteinases (MMPs) and tissue inhibitors of metalloproteinases (TIMPs), and collagen deposition [60, 64, 65].

The anti-inflammatory and immune-modulatory properties of MSCs make allogeneic transplantation possible [66]. Allogeneic human MSCs and some xenogeneic MSCs can avoid acute immune rejection through the expression of factor $\mathrm{H}$ and other complementary proteins [67]. They possess the ability to block neutrophil function by supressing the oxidative bursts of both resting and activated neutrophils, while simultaneously preserving neutrophil phagocytic chemotactic functions. Cytokines expressed by MSCs have been shown to play a critical role in immune-modulation mechanisms [68]. Quiescent MSCs mainly produce the immune-regulatory cytokines TGF- $\beta$ and IL- 10 , whereby TGF- $\beta$ inhibits IL-2, major histocompatibility complex II (MHC-II), and co-stimulatory factor expression in dendritic cells (DCs) and T-cells, while IL-10 inhibits antigenpresenting cell maturation and suppresses $\mathrm{T}$ helper 17 cell (Th17) generation [68].

MSCs also produce a wealth of bioactive trophic factors, which simulate adjacent parenchymal cells to kick-start the process of repairing damaged tissue [69]. In wound repair, MSCs play an important role in promoting angiogenesis, a complex process controlled by both pro-angiogenic and anti-angiogenic factors. The ability of MSCs to mediate angiogenesis has been shown in a study where BM-MSCs engrafted in a skin wound released pro-angiogenic factors [70]. Human AdSCs have also been shown to secrete growth factors such as platelet-derived growth factor (PDGF), VEGF, and TGF- $\beta$, which are directly involved in angiogenesis and wound healing, and resulted in increased microvessel formation in a murine burn model [71]. A study using the porcine model also confirmed that AdSC delivery can accelerate angiogenesis in a dose dependent manner in deep partial thickness burns [72]. 
MSCs play a primary role in promoting cell proliferation and enhancing overall tissue repair. Cell cycle analysis and anti-proliferating cell nuclear antigen (PCNA) staining in a rat skin expansion model showed that AdSC-treated injuries had significantly higher percentages of cell proliferation compared to fibroblast-treated injuries [18]. The proliferating cells were predominantly observed at the stratum basale and hair follicles. In another study using a rat skin wound model, regions treated with AdSCs showed increased rates of cell proliferation in granulation tissue. This was thought to be due to the influence of AdSCs on activated macrophages, which released significant amounts of fibroblast growth factor (FGF), a cytokine directly involved in the epithelial proliferation process [73]. The majority of studies included in this review observed that MSCs combined with a biomaterial scaffold have the capacity to accelerate wound healing, promote re-epithelisation, and induce skin tissue regeneration.

\section{Dose of stem cells}

Although an interesting point of investigation, only one of the include studies compared the effectiveness of using different doses of MSCs in wound healing, by incorporating them into a dermal regeneration template [74]. This porcine study used umbilical cord MSCs, and surprisingly found that a low dose range of $200-40,000$ cells $/ \mathrm{cm}^{2}$ stem cells was the most effective in regenerating full-thickness burn excised wounds. This was followed by a middle dose range of $2-4 \times 10^{5}$ cells $/ \mathrm{cm}^{2}$, and lastly a high dose of $2 \times 10^{6}$ cells $/ \mathrm{cm}^{2}$. The lower doses proved more effective in several aspects of skin repair, including accelerated wound healing, reduced scarring, and enhanced neovascularisation. Moreover, epidermal thickness was observed to be highest in the low dose group and decreased with increasing cell dose. These findings are potentially paradigm shifting among current beliefs in skin tissue regeneration, as previous studies hypothesised that a larger dose of stem cells was required to enhance skin healing [75-81]. To explain these findings, it was hypothesised that excessive amounts of transplanted stem cells might proliferate to the maximum capacity and consume all available resources, leading to possible nutrient deficiency and hypoxia in the wound environment that then catalysed cell death [74].

\section{Cell culture method: 2D vs 3D}

MSCs cultured in 3D have the characteristics of enhanced differentiation capacity, upregulated pluripotency marker gene expression, and delayed replicative senescence [82]. Although there is no research to directly compare the effects of $2 \mathrm{D}$ versus $3 \mathrm{D}$ culture on burn wound healing, studies on other types of tissue regeneration show promising results.
An in vitro study investigating the therapeutic effects of 3D spheroids formed from human MSCs for acute kidney injury showed that 3D culture enhanced the production of extracellular matrix (ECM) proteins including collagen I, fibronectin and laminin, when compared to cells cultured in 2D [83]. The 3D spheroids also exhibited stronger anti-oxidative and anti-apoptotic properties. When injected into the kidney of rat models, 3D cultured cells were more effective in protecting against apoptosis, reducing tissue damage, enhancing vascularisation, and improving overall renal function than 2D cultured cells. Another study examined the effects of human MSC secretome on corneal wound healing in rabbits [84]. Concentrations of bioactive factors such as HGF and ICAM-1 increased by up to five fold in the secretome produced by MSCs cultured on 3D fibre matrices compared to those on $2 \mathrm{D}$ culture dishes. The 3D cultured MSCs were effective at facilitating wound healing in corneal fibroblast cells and explanted corneas.

$3 \mathrm{D}$ bioprinting is a recent technological advance that can be used to produce 3D cellular or tissue structures, possessing the advantages of high resolution, flexible operation, repeatable printing, and high-throughput output, making it an appealing option for generating bioactive constructs for the clinical treatment of skin burns [85]. Since the first $3 \mathrm{D}$ bioprinting technology was reported, tissue engineering has made great progress in this realm, with the field now progressing towards printing mini-sized organs and tissues [86]. Using 3D bioprinting, different types of cells can be deposited at specific locations to form multilayer structures and build anatomically-similar tissues [87]. In an example where 3D bioprinting was applied in skin tissue engineering, a dermal-derived ECM (dECM) bioink was used to tackle the rapid degradation and high shrinkage seen in traditional collagen-based bioinks. The printed mixture of adipose tissue-derived MSCs and endothelial progenitor cells, together with skin-derived dECM was used to produce pre-vascularised skin grafts, which effectively accelerated skin healing in a mouse excisional wound model [88].

\section{Type of graft}

All included studies except one used allogeneic or xenogeneic grafts. One study used isogeneic cells from genetically identical clones [89].

Autologous skin grafts have remained the standard of care for clinical skin reconstruction and wound coverage, typically involving the use of split-thickness skin grafts (STSGs) and full-thickness skin grafts (FTSGs). Although both have been known to provide good healing outcomes in patients, they are limited by certain drawbacks. STSGs have lower levels of elastin compared to FTSGs and are unable to regenerate full-thickness skin, often undergoing significant contraction following placement [90]. While STSGs can cover 
large wound areas on the recipient, a variety of donor site morbidities can occur including scarring, chronic pain, and infection [91]. FTSGs are more preferable for skin repair since they contain all skin layers as well as the regenerative appendages found in each cutaneous compartment [90]. However, FTSGs have a higher metabolic demand and are limited by the lack of donor skin, restricting their application to smaller wounds. Interestingly, a recently developed autologous homologous skin construct (AHSC) technology makes use of the patient's innate skin regeneration potential to generate full-thickness skin, including all dermal and epidermal components [92]. In this case, a 10-year-old boy who suffered from a large upper torso burn wound was treated with STSGs and developed painful, functionally limiting scar contractions. As alternative treatment, a 17.5 $\mathrm{cm}^{2}$ section of skin was harvested from the groin and sent to be manufactured into AHSC at a biomedical facility. The skin construct was applied to a $200 \mathrm{~cm}^{2}$ wound immediately following excision. The AHSC displayed $100 \%$ graft take, as well as initial postoperative epithelialisation and re-pigmentation which progressed to complete epithelial coverage at 8 weeks. At 11 months, the regenerated skin restored range of movement and showed no adverse scarring, suggesting the potential of this technology in paediatric burn reconstruction.

Allogeneic skin grafts catalyse potent immune responses involving both the innate and adaptive immune system, and their clinical applications need to rely heavily on effective immunosuppression in the recipient [93]. The immunocompromised state of patients with severe burn injuries receiving allogeneic skin grafts may result in delayed rejection, secondary infections, and increased scarring. In sandwich grafting for burn treatment, the skin allograft functions as a biological dressing that sits on top of a widely meshed autograft, to protect the wound bed in the interstices of the autograft [94]. Naturally, the allograft would separate from the wound bed due to gradual rejection, allowing the underlying autograft to complete the process of epithelisation. However, another major concern of using skin allografts is the risk of disease transmission. While the reported rates of disease transmission are sporadic and low, microbial testing is crucial to ensure the safety of the allografts.

Xenogeneic materials such as porcine or fish skin can be used for temporary skin coverage, particularly in large scale or severe burns to stabilise the patient until they can be treated by autologous skin grafting [93]. Xenogeneic grafts contain antigens which are recognised by the immune system as foreign, which can lead to biochemical failure of the graft or even host organism death [95]. For clinical application, chemical treatments may be used that crosslink proteins within xenogeneic tissue, but this may not completely mask important antigens [93]. Although a recent Phase II clinical trial has suggested that a xenograft dressing could achieve re-epithelialization in burn wounds even without autologous split-thickness skin grafting [96], xenografts currently can only be considered a temporary solution for the clinical care of patients with severe burns.

\section{Burn wound model}

The types of preclinical burn models used in the included studies can be divided into thermal burn, radiation burn and surgical wound. Thermal burn was the most common injury used in animal models to test the effectiveness of tissue engineered constructs in burn wound healing. This is because thermal burns from fire, flames or scalds account for approximately $80 \%$ of all reported burns [97]. The metabolic response in burn patients following thermal injury is biphasic, with an initial ebb phase and then a hypermetabolic and catabolic flow phase [98]. The increased metabolic rate results from evaporative heat loss from the burn wound, as well as a central effect of inflammation on the hypothalamus. A study on the standardisation of thermal injuries in the rat model validated the same hypermetabolic response induced by thermal injury that is generally associated with severe burns [99]. Skin samples confirmed that animals receiving thermal burn wounds sustained skin injury across all layers, including complete epidermal destruction and thermal coagulative damage. Burned hair follicles also displayed distinct cellular damage and cytoplasmic swelling.

Surgical wounds were the second most common injury type among the included studies. Surgical wounds are typically created under sterile conditions, and do not result in the same immediate pathophysiological effects seen in conventional burns. Therefore, although surgical skin wound models are more consistent and controlled, they are less representative of clinical burn pathology and responses to treatment due to inherent differences in physiological responses.

Radiation burns are clinically far less common than thermal, electrical and chemical burns, with very different pathophysiological responses. Only 2 of the included studies used radiation burn in their animal models $[100,101]$. Compared to thermal skin burns, radiation burns are characterised by necrosis, paroxysmal and chronic pain resistant to opiates, as well as uncontrolled, successive inflammatory waves [102]. Ulceration and necrosis may extend to deep dermal and underlying muscle structures, with the inflammatory waves inducing severe pain [103]. Furthermore, ionising radiation causes DNA damage which leads to repair responses, genetic mutations, or cell death, with early and late effects. Ultraviolet radiation resulting in 'sunburn' is one of the key inducing factors of squamous cell carcinoma and basal cell carcinoma [104]. Excessive exposure to ultraviolet radiation carries profound health risks including atrophy, pigmentary changes, skin wrinkling, and malignancy [105]. 
As such, radiation burn may not be a highly representative wound model for general burns treatment.

\section{Timeframe}

The delay between establishing the skin wound in the preclinical model and applying the engineered skin product to the wound varied among the included studies, with some applying the tissue engineered product immediately postburn, and others delaying the treatment for up to 10 days. Generally, studies involving burns patients showed that the best clinical outcomes were obtained when burns were excised and grafted at 24-48 $\mathrm{h}$ after the injury [106-108]. In preclinical models, treating burns outside of this optimal period using tissue engineered products may potentially reduce healing rates, although inter-species differences should also be taken into consideration when analysing the results.

There was a large variation in the endpoints of outcome evaluation used in the included studies, ranging from 7 to 90 days post-burn. Some studies also had multiple endpoints at which biopsies were taken or animals were euthanised. The normal wound healing process occurs in three phases: haemostasis and the inflammatory phase (from the time of injury to day 4-6), the proliferative phase (day 4 to 14), and finally maturation and remodelling (day 8 to 1 year or longer) $[60,109]$. Studies where endpoints do not extend beyond the proliferative phase of wound healing would not allow the full effects of wound maturation and remodelling to be assessed, and therefore may not be indicative of long-term healing response. Endpoints of 1 year or longer in preclinical models would obviously be ideal, particularly for larger animals due to their longer lifespan, but this is often difficult to implement due to housing requirements and increased costs. Interestingly, despite size differences, there were no major variations in the time period required for the start of wound recovery between small and large animals, with the vast majority of included studies reporting that wound filling with granulation tissue occurred between 7 to 21 days, and only one porcine study reporting 28 days.

\section{Scaffolds}

Biomaterials used for tissue regeneration can be generally divided into natural and synthetic biomaterials [110]. Natural biomaterials derived from biological and plant sources have been widely studied in tissue engineering because of their biocompatibility, bioactivity, and biodegradation properties, many of which possess similar structure to natural ECM. When placed in biological systems, natural biomaterials release products during biodegradation that have minimal cytotoxicity, and provide biomimetic properties to support cell adhesion and function [110]. Collagen, chitosan, and fibrin are some common examples of natural biomaterials used by studies included in this review, and are derived from protein and polysaccharide sources [111].

Collagen is a naturally occurring protein and an ubiquitous component of the skin ECM, which is commonly used as a scaffold material due to its mechanical and cell-adhesive properties [112]. Although collagen scaffolds can undergo fast biodegradation and also result in wound contraction [113], this can be mitigated by crosslinking [114]. Chitosan is a natural polymer derived from chitin. It is a popular material choice for skin regeneration scaffolds since it has good biocompatibility with skin cells, is anti-microbial, promotes wound healing, and reduces scar formation [115]. 3D chitosan nanofibrillar scaffolds produced by electrospinning showed great ability to promote skin repair both in vitro and in a mouse model [116]. However, applications of pure chitosan are often limited by low mechanical durability [117]. When combined together, collagen/chitosan scaffolds have shown the ability to promote keratinocyte migration and wound re-epithelisation in an ex vivo human skin wound model [118], as well as cutaneous wound healing in murine models when combined with BM-MSCs [119, 120]. Scaffolds with this material combination can have many advantages for skin repair such as mechanical stability, antibacterial function, and accelerated collagen synthesis through fibroblast recruitment, diluting the drawbacks of the individual materials.

Fibrin is another versatile biopolymer that can be used as a scaffold for skin regeneration. It can improve skin graft success rates, support keratinocyte and fibroblast growth [121], and convey better angiogenic properties than collagen scaffolds [112]. However, fibrin hydrogels used in skin tissue engineering also exhibit several limitations: gel shrinkage during the formation of flat sheets, low mechanical stiffness, and rapid biodegradation before the formation of vital tissue structures [121]. The usefulness of fibrin hydrogels can be extended by incorporating ECM-derived proteins to improve their biological activity, such as fibronectin, vitronectin and laminin. Injectable fibrin scaffolds that slowly release a cocktail of growth factors including PDGF, VEGF, TGF- $\beta 1$, IGF, FGF, and EGF can promote skin healing through cell proliferation, collagen deposition, and tissue revascularisation [122].

Composite scaffolds can combine the advantages of several biomaterials to enhance skin regeneration, and compensate for the limitations of individual materials. One of the included studies seeded MSCs onto a biodegradable hybrid hydrogel synthesised from unsaturated argininebased poly(ester amide) and chitosan derivative [123]. These MSC-seeded hybrid gels promoted wound closure, re-epithelialisation, granulation tissue formation, and vascularisation of third degree burns in mice. They also increased antiinflammatory IL-10 expression and M2-like macrophages, 
and reduced inflammatory TNF- $\alpha$ expression and M1-like macrophages. While the hydrogels alone were seen to promote vascularisation, they were much more effective when seeded with MSCs. In other studies, 3D printing has been used to fabricate composite scaffolds with new material combinations for skin repair, such as a gelatine-sulfonated silk composite scaffold to overcome the deficiency of dermal vascularisation [124]. As a collagen derivative, gelatine possesses great biocompatibility and fast degradation rate, which exhibits enhanced mechanical support when combined with sulfonated silk. This 3D printed scaffold was shown to promote the regeneration of skin-like tissues in a rat skin defect model.

Another interesting but less commonly explored natural biomaterial for skin repair is the acellular amniotic membrane, obtained from the placenta following caesarean section delivery, conveying excellent biocompatibility as well as anti-inflammatory and anti-microbial effects [125]. The amniotic membrane includes amniotic mesenchymal cells (AMCs) and amniotic epithelial cells (AECs). AMCs are capable of differentiating into all three germ layers and secreting anti-inflammatory cytokines such as PGE2, IDO, HGF and TGF- $\beta$ [126]. AECs have been shown to express HLA-G antigens on their surface, which are involved in the induction of immune tolerance and can effectively reduce the risk of post-transplantation rejection [126].

Synthetic polymers are also used as scaffold materials for skin regeneration as they eliminate the risk of disease transmission, and their fabrication processes can be more precisely controlled to give tailorable mechanical and chemical properties. However, most synthetic polymers lack bioactivity unless further modified [127]. An example is poly(vinyl alcohol) (PVA), which has good biocompatibility and also exhibits potential as a protein delivery system [127]. Modified PVA hydrogels were shown to be biocompatible and not elicit severe inflammatory responses for up to 12 weeks after in vivo implantation in mice. Poly (ethylene glycol) (PEG) is another commonly used synthetic polymer in skin tissue engineering [128]. PEG-based amphiphilic copolymers have versatile uses as scaffold materials, where the hydrophobic polyester components provide biodegradation and protein adhesion, while the hydrophilic PEG blocks provide better mechanical properties and elasticity [129].

\section{Other added substances}

Other substances have been added to tissue engineered constructs involving stem cells in combination with scaffolds to improve their bioactivity and functional characteristics for skin repair in the included studies. Other cell types added in combination with stem cells can include dermal papilla cells, dermal fibroblasts, and keratinocytes [130]. Dermal papilla cells are mesenchymal cells found in the skin which regulate hair follicle growth and development [131]. Dermal fibroblasts are extensively involved in the natural wound healing process, particularly during the proliferative phase by performing collagen synthesis and contraction. Fibroblast proliferation can be induced by a variety of growth factors including PDGF, IFN- $\gamma$, IL-1, and TNF- $\alpha$ [109]. Keratinocytes migrate, proliferate and differentiate into the epidermis during wound healing, and also promote angiogenesis by secreting VEGF [109].

A range of bioactive substances have been added to tissue engineered constructs in the included studies, including spirulina biomass, hematoporphyrin, and the PDGF-B gene. Spirulina is a blue-green microalgae that has been shown to aid skin wound healing by promoting angiogenesis, immune cell infiltration, epithelialisation, ECM deposition, and wound contraction [132], as well as by enhancing fibroblast viability and anti-oxidative mechanisms [133]. Hematoporphyrin is a photosensitiser that can generate reactive oxygen species (ROS), providing anti-microbial effects while promoting cell proliferation, and regulating inflammatory factors and collagen remodelling [134]. PDGF-B is a growth factor that recruits pericytes essential for the stabilisation and maturation of vascular structures [135]. PDGF is produced by several cell types, including macrophages, monocytes, fibroblasts, smooth muscle cells, and endothelial cells, which can then result in chemotaxis [109]. In skin repair, PDGF-B acts as a chemical inducer that can catalyse repair cells to migrate from the wound edge to the wound bed [136], as well as stimulate the proliferation of repair cells to increase the formation of granulation tissue [137]. In addition to these, VEGF is a common pro-angiogenic factor utilised in skin repair to accelerate the early phases of wound healing by promoting neovascularisation [138]. EGF is another commonly used growth factor recognised for its therapeutic functions in stimulating skin cell growth, proliferation and differentiation [139].

\section{Outlook and perspectives}

While stem cells have attracted significant attention in skin tissue engineering due to their ability to differentiate into tissue-specific cells and/or secrete bioactive factors to aid repair, several hurdles need to be overcome before stem cell-based products can become a standard method in clinical burns treatment. A primary hurdle in the translation of stem cell-based tissue engineered skin arises from the inherent discrepancies in skin structure and physiological response between humans and animal models [37]. For instance, murine models cannot fully replicate the pathophysiological and systemic responses to burns that humans demonstrate, which reduces the translational relevance of products tested using such models. While porcine models 
provide a better prediction of clinical treatment outcomes, the majority of current studies are limited in scope due to practical constraints such as housing requirements, cost, and ethics. For these reasons, the generation of in vitro skin organoids may bridge a gap between animal models and clinical response to treatment. For instance, skin organoids have been generated in $3 \mathrm{D}$ culture using a homogenous population of mouse pluripotent stem cells, which replicated some of the characteristics of native skin including the development of new hair follicles [140]. The same group then developed a human skin organoid, by guiding human iPSCs through a month-long process of differentiation to generate complex hair-bearing human skin tissue [141]. These skin organoids may be used to model burn wounds for testing new skin substitutes, offering short modelling times and the potential to be made patient-specific [142].

Recent developments in biofabrication technologies such as 3D bioprinting are enabling the production of anatomically-similar skin constructs, which can replicate the essential features and native functions of human skin, and be used either as a test model for new skin substitutes or developed as a therapeutic product. 3D bioprinting provides the advantages of reproducibility and customisability, allowing for accurate cell positioning and control in preparing biomimetic tissue structures [143]. Using 3D bioprinting with a medical grade bioink and mechanically extracted human skin cells, a dermis could be reconstituted in vitro, and skin cellular components could also be printed directly onto an in vivo skin wound [144]. Experiments in a murine model suggested that this technology was feasible and well-tolerated, with potential for development into a clinical treatment for patients with severe burns through a single intraoperative step. In another approach, a collagen and alginate bioink in combination with keratinocytes and fibroblasts were printed in a 3D scaffold, where cells were shown to form dense structures similar to human skin as they could migrate and proliferate on the scaffold [143]. The use of additive manufacturing in skin tissue engineering could improve standardisation and reproducibility of patient outcomes, and assist the translation of new therapeutic products into clinical applications.

The development of new biomaterials could further augment the formation of biomimetic skin constructs, potentially progressing towards full-thickness skin regeneration. For example, antibiotic-based silk fibroin (ABSF) films can accelerate burn wound healing by increasing fibroblast viability and adhesion, as well as by reducing the chance of infection at the wound site [145]. Additionally, a dextran-based hydrogel was found to stimulate neovascularisation within the first week of application when used to treat third degree burns in a pig model, resulting in rapid healing and wound closure, increased re-epithelisation and ECM remodelling, and superior reinnervation of newly formed skin tissue compared to conventional dressing treatment [146].

Future directions for using stem cells in burns treatment could involve not only the direct use of cells themselves, but also their secretory products such as extracellular vesicles (EVs), including exosomes (small EVs) and microvesicles (large EVs). The emerging role of EVs both as disease biomarkers and therapeutic agents is being increasingly recognised, as they have been identified to play key roles in intercellular communication [147, 148]. Stem cell-derived EVs have been shown to replicate the pro-regenerative functions of their parent cells, such as promoting cell proliferation and angiogenesis, and supressing apoptosis [148], pointing to their potential in being used as novel therapeutics for skin repair and burns treatment [149], possibly obviating the need to use cells and navigate associated practical hurdles. EVs from human iPSCs and MSCs are considered to have a key role in paracrine signalling, and can enhance healing in burn wounds without the associated stem cells [150]. For instance, EVs from iPSC-derived MSCs have been shown to enhance the migration of human dermal fibroblasts to stimulate vascularisation, effectively promoting wound healing by reducing scarring and improving collagen maturity [151]. In mouse model of a second degree burn, iPSC-derived EVs played a significant role in enhancing skin re-epithelisation and increasing numbers of keratinocytes [152]. MSCderived EVs have similarly been reported to promote skin regeneration and accelerate would healing [147]. Part of the mechanisms leading to these effects may be related to the immunomodulatory properties of the parent MSCs, whereby their ability to promote anti-inflammatory M2 microphage polarisation, aid B-cell regulation, and suppress effector T-cells are replicated in the MSC-derived EVs $[153,154]$.

Nanotechnological approaches are now being increasingly explored to provide innovative tissue engineering solutions for treating burn wounds. Nanoparticles could be used for temporary or sustained controlled delivery of growth factors [155]. For instance, a nanofibrous skin substitute was created using electrospinning to allow programmable release of multiple angiogenic growth factors through gelatine nanoparticles [156]. This construct was designed to deliver endothelial growth factor and basic fibroblast growth factor in the early stage of wound healing to accelerate epithelisation and vascular sprouting, while PDGF and VEBF are released in the later stages to induce blood vessel maturation. Moreover, micro-/nano-robots are being increasingly explored as an exciting new field to provide targeted drug delivery that can be controlled by external sources such as magnetic forces, light, or ultrasound [157]. These could be used to deliver a range of cargo from genes and biomacromolecules to cells, and might find new applications in bioengineered skin constructs. 
Nanosensors are another exciting area of development that could be integrated into tissue engineering solutions for real-time monitoring of skin repair, using biomarkers generated during the process of wound healing. For instance, novel fluorescent magnesium hydroxide nanosheets have been integrated with electrospun fibres and agarose gels to create multifunctional topical wound dressings [158]. The nanosheets provided the dressing with potent antimicrobial properties, with a strong fluorescence signature that could be used to assess the dressing degradation and functional antimicrobial capacity. Moreover, $\mathrm{pH}$-responsive changes in fluorescence could act as a probe for wound acidification as an indicator of healthy wound healing. Such approaches could be considered for developing new skin wound dressings with biosensing capabilities.

Tissue engineering and regenerative medicine is rapidly evolving field. From our discussions in this review, it is evident that the use of stem cell-based tissue engineering approaches, augmented by biomaterials to assist skin repair in preclinical models of burn wounds has demonstrated promising outcomes, whereby full-thickness burns have been regenerated together with accessory structures such as hair follicles [50] in some cases. Nevertheless, further studies need to be conducted to test the safety and efficacy of these methods, and address possible variations associated with donors or treatment procedures before stem cell-based tissue engineered skin can be implemented for clinical burns treatment in human patients. This can be conducted through the optimisation of parameters, including those assessed in this review - cell types and tissue sources, cell dosage, supporting biomaterials, and treatment timeframe. Improved reporting would also help with standardisation of results from preclinical studies, particularly on quantitative data such as the thickness of newly formed skin and incidence of complications, which were rarely specified in the studies included in this review. Furthermore, as treatment responses in animal models do not directly translate to humans, it is vital that more physiologically relevant preclinical models are used to assess new therapies, or that new technologies are used to create in vitro representations of human tissue to aid proof of concept studies. By combining cross-disciplinary advances in regenerative medicine, incorporating stem cells, new biomaterials, manufacturing techniques, and nanotechnological advances, tissue engineered skin will move closer to becoming a reality for the clinical treatment of full-thickness burns.

Supplementary Information The online version contains supplementary material available at https://doi.org/10.1007/s12015-022-10341-z.

Funding Open Access funding enabled and organized by CAUL and its Member Institutions. The authors acknowledge funding support from the National Health and Medical Research Council (Australia; GNT1120249), National Natural Science Foundation of China (81802204), and China Postdoctoral Science Foundation (2020M671453).

Data Availability Not applicable.

Code availability Not applicable.

\section{Declarations}

Ethics approval Not applicable.

Consent to participate Not applicable.

Consent for publication Not applicable.

Competing interests The authors have no competing interests to declare that are relevant to the content of this article.

Open Access This article is licensed under a Creative Commons Attribution 4.0 International License, which permits use, sharing, adaptation, distribution and reproduction in any medium or format, as long as you give appropriate credit to the original author(s) and the source, provide a link to the Creative Commons licence, and indicate if changes were made. The images or other third party material in this article are included in the article's Creative Commons licence, unless indicated otherwise in a credit line to the material. If material is not included in the article's Creative Commons licence and your intended use is not permitted by statutory regulation or exceeds the permitted use, you will need to obtain permission directly from the copyright holder. To view a copy of this licence, visit http://creativecommons.org/licenses/by/4.0/.

\section{References}

1. Gravitz, L. (2018). Skin. Nature, 563(7732), S83.

2. WHO. Burns: World Health Organization; 2018. Retrieved from https://www.who.int/news-room/fact-sheets/detail/burns. Accessed 22 Nov 2021

3. AIHW: Pointer $S$ \& Tovell A 2016. Hospitalised burn injuries Australia 2013-14. Cat. no. INJCAT 178. Canberra: AIHW. Retrieved from https://www.aihw.gov.au/reports/injury/hospi talised-burn-injuries-australia-2013-14. Accessed 22 Nov 2021.

4. Xie, B., Xiao, S.-C., Zhu, S.-H., \& Xia, Z.-F. (2012). Evaluation of long term health-related quality of life in extensive burns: A 12-year experience in a burn center. Burns, 38(3), 348-355.

5. Wasiak, J., Paul, E., Lee, S. J., Mahar, P., Pfitzer, B., Spinks, A., Cleland, H., \& Gabbe, B. (2014). Patterns of recovery over 12 months following a burn injury in Australia. Injury, 45(9), 1459-1464.

6. Shahin, H., Elmasry, M., Steinvall, I., Söberg, F., \& El-Serafi, A. (2020). Vascularization is the next challenge for skin tissue engineering as a solution for burn management. Burns and Trauma, 8 , tkaa022.

7. Shiffman, M. A., Low, M. (2020). Burns, infections and wound management (1st ed. 2020). Cham: Springer International Publishing. https://doi.org/10.1007/978-3-030-10686-7

8. Weng, T., Wu, P., Zhang, W., Zheng, Y., Li, Q., Jin, R., Chen, H., You, C., Guo, S., Han, C., \& Wang, X. (2020). Regeneration of skin appendages and nerves: Current status and further challenges. Journal of Translational Medicine, 18(1), 53.

9. Zaidi, Z., \& Lanigan, S. W. (2010). Skin: structure and function Dermatology in Clinical Practice (pp. 1-15): Springer. 
10. Martin, P. (1997). Wound healing-aiming for perfect skin regeneration. Science, 276(5309), 75-81.

11. Wang, Y., Beekman, J., Hew, J., Jackson, S., Issler-Fisher, A. C., Parungao, R., Lajevardi, S. S., Li, Z., \& Maitz, P. K. M. (2018). Burn injury: Challenges and advances in burn wound healing, infection, pain and scarring. Advanced Drug Delivery Reviews, $123,3-17$.

12. Rubis, B. A., Danikas, D., Neumeister, M., Williams, W. G., Suchy, H., \& Milner, S. M. (2002). The use of split-thickness dermal grafts to resurface full thickness skin defects. Burns, 28(8), $752-759$.

13. Greenhalgh, D. G. (2019). Management of burns. New England Journal of Medicine, 380(24), 2349-2359.

14. Halim, A. S., Khoo, T. L., \& Mohd Yussof, S. J. (2010). Biologic and synthetic skin substitutes: An overview. Indian Journal of Plastic Surgery, 43(Suppl), S23-S28.

15. Blome-Eberwein, S. A., Amani, H., Lozano, D. D., Gogal, C., Boorse, D., \& Pagella, P. (2021). A bio-degradable synthetic membrane to treat superficial and deep second degree burn wounds in adults and children -4 year experience. Burns, 47(4), 838-846.

16. Frear, C. C., Cuttle, L., McPhail, S. M., Chatfield, M. D., Kimble, R. M., \& Griffin, B. R. (2020). Randomized clinical trial of negative pressure wound therapy as an adjunctive treatment for small-area thermal burns in children. British Journal of Surgery, 107(13), 1741-1750.

17. Priya, S. G., Jungvid, H., \& Kumar, A. (2008). Skin tissue engineering for tissue repair and regeneration. Tissue engineering Part B: Reviews, 14(1), 105-118.

18. Sheng, L., Yang, M., Liang, Y., \& Li, Q. (2013). Adipose tissue-derived stem cells (ADSCs) transplantation promotes regeneration of expanded skin using a tissue expansion model. Wound Repair and Regeneration, 21(5), 746-754.

19. Kundu, B., Rajkhowa, R., Kundu, S. C., \& Wang, X. (2013). Silk fibroin biomaterials for tissue regenerations. Advanced Drug Delivery Reviews, 65(4), 457-470.

20. Mohamed Abudhahir, K., Murugesan, R., Vijayashree, R., Selvamurugan, N., Chung, T.-W., \& Moorthi, A. (2021). Metal doped calcium silicate biomaterial for skin tissue regeneration in vitro. Journal of Biomaterials Applications, 36(1), 140-151.

21. Kalai Selvan, N., Shanmugarajan, T. S., \& Uppuluri, V. N. V. A. (2020). Hydrogel based scaffolding polymeric biomaterials: Approaches towards skin tissue regeneration. Journal of Drug Delivery Science and Technology, 55, 101456.

22. Zhou, F., Hong, Y., Liang, R., Zhang, X., Liao, Y., Jiang, D., Zhang, J., Sheng, Z., Xie, C., Peng, Z., Zhuang, X., Bunpetch, V., Zou, Y., Huang, W., Zhang, Q., Alakpa, E. V., Zhang, S., \& Ouyang, H. (2020). Rapid printing of bio-inspired 3D tissue constructs for skin regeneration. Biomaterials, 258, 120287.

23. Boyce, S. T. (2001). Design principles for composition and performance of cultured skin substitutes. Burns, 27(5), 523-533.

24. Cammarota, M., D’Agostino, A., Campitiello, F., Mancone, M., Ricci, G., Corte, A. D., Guerniero, R., Stellavato, A., Schiraldi, C., \& Canonico, S. (2021). Hard-to-heal wound treated with Integra Flowable Wound Matrix: Analysis and clinical observations. Journal of Wound Care, 30(8), 644-652.

25. De Francesco, F., Busato, A., Mannucci, S., Zingaretti, N., Cottone, G., Amendola, F., De Francesco, M., Merigo, F., Riccio, V., Vaienti, L., Parodi, P. C., Sbarbati, A., \& Riccio, M. (2020). Artificial dermal substitutes for tissue regeneration: Comparison of the clinical outcomes and histological findings of two templates. Journal of International Medical Research. https://doi.org/10.1177/0300060520945508

26. Shahrokhi, S., Arno, A., \& Jeschke, M. G. (2014). The use of dermal substitutes in burn surgery: Acute phase. Wound Repair and Regeneration, 22(1), 14-22.
27. Duscher, D., Barrera, J., Wong, V. W., Maan, Z. N., Whittam, A. J., Januszyk, M., \& Gurtner, G. C. (2016). Stem cells in wound healing: The future of regenerative medicine? A minireview. Gerontology, 62(2), 216-225.

28. Balaji, S., Keswani, S. G., \& Crombleholme, T. M. (2012). The role of mesenchymal stem cells in the regenerative wound healing phenotype. Advances in Wound Care, 1(4), 159-165.

29. Fuchs, E., \& Horsley, V. (2008). More than one way to skin. Genes \& Development, 22(8), 976-985.

30. Abdul Kareem, N., Aijaz, A., \& Jeschke, M. G. (2021). Stem cell therapy for burns: Story so far. Biologics: Targets and Therapy, 15, 379-397.

31. Dehkordi, A. N., Babaheydari, F. M., Chehelgerdi, M., \& Dehkordi, S. R. (2019). Skin tissue engineering: Wound healing based on stem-cell-based therapeutic strategies. Stem Cell Research \& Therapy, 10(1), 111.

32. Choudhury, S., Surendran, N., \& Das, A. (2021). Recent advances in the induced pluripotent stem cell-based skin regeneration. Wound Repair and Regeneration, 29(5), 697-710.

33. Riha, S. M., Maarof, M., \& Fauzi, M. B. (2021). Synergistic effect of biomaterial and stem cell for skin tissue engineering in cutaneous wound healing: A concise review. Polymers, 13(10), 1546.

34. Henriksen, J. L., Sørensen, N. B., Fink, T., Zachar, V., \& Porsborg, S. R. (2020). Systematic review of stem-cell-based therapy of burn wounds: Lessons learned from animal and clinical studies. Cells, 9(12), 2545.

35. Tricco, A. C., Lillie, E., Zarin, W., O'Brien, K. K., Colquhoun, H., Levac, D., Moher, D., Peters, M. D. J., Horsley, T., Weeks, L., Hempel, S., Akl, E. A., Chang, C., McGowan, J., Stewart, L., Hartling, L., Aldcroft, A., Wilson, M. G., Garritty, C., Lewin, S., Godfrey, C. M., Macdonald, M. T., Langlois, E. V., SoaresWeiser, K., Moriarty, J., Clifford, T., Tuncalp, O., Straus, S. E (2018). PRISMA extension for scoping reviews (PRISMAScR): Checklist and explanation. Annals of Internal Medicine, 169(7), 467-473.

36. Moher, D., Liberati, A., Tetzlaff, J., \& Altman, D. G. (2009). Preferred reporting items for systematic reviews and meta-analyses: The PRISMA statement. BMJ, 339(7716), e78-336.

37. Abdullahi, A., Amini-Nik, S., \& Jeschke, M. G. (2014). Animal models in burn research. Cellular and Molecular Life Sciences, 71(17), 3241-3255.

38. Dorsett-Martin, W. A. (2004). Rat models of skin wound healing: A review. Wound repair and regeneration, 12(6), 591-599.

39. Hew, J. J., Parungao, R. J., Shi, H., Tsai, K.H.-Y., Kim, S., Ma, D., Malcolm, J., Li, Z., Maitz, P. K., \& Wang, Y. (2020). Mouse models in burns research: Characterisation of the hypermetabolic response to burn injury. Burns, 46(3), 663-674.

40. Sheu, S.-Y., Wang, W.-L., Fu, Y.-T., Lin, S.-C., Lei, Y.-C., Liao, J.-H., Tang, N.-Y., Kuo, T.-F., \& Yao, C.-H. (2014). The pig as an experimental model for mid-dermal burns research. Burns, 40(8), 1679-1688.

41. Sullivan, T. P., Eaglstein, W. H., Davis, S. C., \& Mertz, P. (2001). The pig as a model for human wound healing. Wound Repair and Regeneration, 9(2), 66-76.

42. Middelkoop, E., van den Bogaerdt, A. J., Lamme, E. N., Hoekstra, M. J., Brandsma, K., \& Ulrich, M. M. W. (2004). Porcine wound models for skin substitution and burn treatment. Biomaterials, 25(9), 1559-1567.

43. Ribitsch, I., Baptista, P. M., Lange-Consiglio, A., Melotti, L., Patruno, M., Jenner, F., Schnabl-Feichter, E., Dutton, L. C., Connolly, D. J., van Steenbeek, F. G., Dudhia, J., \& Penning, L. C. (2020). Large animal models in regenerative medicine and tissue engineering: To do or not to do. Frontiers in Bioengineering and Biotechnology, 8, 972. 
44. Yang, M., Li, Q., Sheng, L., Li, H., Weng, R., \& Zan, T. (2011). Bone marrow-derived mesenchymal stem cells transplantation accelerates tissue expansion by promoting skin regeneration during expansion. Annals of Surgery, 253(1), 202-210.

45. Fennema, E. M., Renard, A. J. S., Leusink, A., van Blitterswijk, C. A., \& de Boer, J. (2009). The effect of bone marrow aspiration strategy on the yield and quality of human mesenchymal stem cells. Acta Orthopaedica, 80(5), 618-621.

46. Nakao, N., Nakayama, T., Yahata, T., Muguruma, Y., Saito, S., Miyata, Y., Yamamoto, K., \& Naoe, T. (2010). Adipose tissuederived mesenchymal stem cells facilitate hematopoiesis in vitro and in vivo: Advantages over bone marrow-derived mesenchymal stem cells. The American Journal of Pathology, 177(2), 547-554.

47. Bajek, A., Gurtowska, N., Olkowska, J., Maj, M., Kaźmierski, Ł, Bodnar, M., Marszałek, A., Dębski, R., \& Drewa, T. (2017). Does the harvesting technique affect the properties of adiposederived stem cells? - the comparative biological characterization. Journal of Cellular Biochemistry, 118(5), 1097-1107.

48. Luo, G., Cheng, W., He, W., Wang, X., Tan, J., Fitzgerald, M., $\mathrm{Li}, \mathrm{X}$., \& Wu, J. (2010). Promotion of cutaneous wound healing by local application of mesenchymal stem cells derived from human umbilical cord blood: MSC from hUCB could promote skin wound healing. Wound Repair and Regeneration, 18(5), 506-513.

49. Friedman, R., Betancur, M., Boissel, L., Tuncer, H., Cetrulo, C., \& Klingemann, H. (2007). Umbilical cord mesenchymal stem cells: Adjuvants for human cell transplantation. Biology of Blood and Marrow Transplantation, 13(12), 1477-1486.

50. Liu, F., Zhou, H., Du, W., Huang, X., Zheng, X., Zhang, C., Hu, H., Wang, J., \& Quan, R. (2020). Hair follicle stem cells combined with human allogeneic acellular amniotic membrane for repair of full thickness skin defects in nude mice. Journal of Tissue Engineering and Regenerative Medicine, 14(5), 723-735.

51. Mathur, A. N., Zirak, B., Boothby, I. C., Tan, M., Cohen, J. N., Mauro, T. M., Mehta, P., Lowe, M. M., Abbas, A. K., Ali, N., \& Rosenblum, M. D. (2019). Treg-cell control of a CXCL5-IL-17 inflammatory axis promotes hair-follicle-stem-cell differentiation during skin-barrier repair. Immunity, 50(3), 655-667.e654.

52. Ledesma-Martínez, E., Mendoza-Núñez, V. M., \& SantiagoOsorio, E. (2016). Mesenchymal stem cells derived from dental pulp: A review. Stem Cells International, 2016, 4709572.

53. Abbas, O. L., Özatik, O., Gönen, Z. B., Öğüt, S., Özatik, F. Y., Salkın, H., \& Musmul, A. (2019). Comparative analysis of mesenchymal stem cells from bone marrow, adipose tissue, and dental pulp as sources of cell therapy for zone of stasis burns. Journal of Investigative Surgery, 32(6), 477-490.

54. Ding, D.-C., Shyu, W.-C., \& Lin, S.-Z. (2011). Mesenchymal Stem Cells. Cell transplantation, 20(1), 5-14.

55. Bartholomew, A., Sturgeon, C., Siatskas, M., Ferrer, K., McIntosh, K., Patil, S., Hardy, W., Devine, S., Ucker, D., Deans, R., Moseley, A., \& Hoffman, R. (2002). Mesenchymal stem cells suppress lymphocyte proliferation in vitro and prolong skin graft survival in vivo. Experimental Hematology, 30(1), 42-48.

56. Wang, Y., Chen, X., Cao, W., \& Shi, Y. (2014). Plasticity of mesenchymal stem cells in immunomodulation: Pathological and therapeutic implications. Nature Immunology, 15(11), 1009-1016.

57. Ren, G., Zhang, L., Zhao, X., Xu, G., Zhang, Y., Roberts, A. I., Zhao, R. C., \& Shi, Y. (2008). Mesenchymal stem cell-mediated immunosuppression occurs via concerted action of chemokines and nitric oxide. Cell Stem Cell, 2(2), 141-150.

58. Lee, D. E., Ayoub, N., \& Agrawal, D. K. (2016). Mesenchymal stem cells and cutaneous wound healing: Novel methods to increase cell delivery and therapeutic efficacy. Stem Cell Research \& Therapy, 7, 37.
59. Smith, A. N., Willis, E., Chan, V. T., Muffley, L. A., Isik, F. F., Gibran, N. S., \& Hocking, A. M. (2010). Mesenchymal stem cells induce dermal fibroblast responses to injury. Experimental Cell Research, 316(1), 48-54.

60. Maxson, S., Lopez, E. A., Yoo, D., Danilkovitch-Miagkova, A., $\&$ LeRoux, M. A. (2012). Concise review: Role of mesenchymal stem cells in wound repair. Stem Cells Translational Medicine, 1(2), 142-149.

61. Liu, S., Jiang, L., Li, H., Shi, H., Luo, H., Zhang, Y., Yu, C., \& Jin, Y. (2014). Mesenchymal stem cells prevent hypertrophic scar formation via inflammatory regulation when undergoing apoptosis. Journal of Investigative Dermatology, 134(10), 2648-2657.

62. Dabrowska, S., Andrzejewska, A., Janowski, M., \& Lukomska, B. (2021). Immunomodulatory and regenerative effects of mesenchymal stem cells and extracellular vesicles: Therapeutic outlook for inflammatory and degenerative diseases. Frontiers in Immunology, 11, 591065.

63. Laverdet, B., Micallef, L., Lebreton, C., Mollard, J., Lataillade, J. J., Coulomb, B., \& Desmouliere, A. (2014). Use of mesenchymal stem cells for cutaneous repair and skin substitute elaboration. Pathologie Biologie, 62(2), 108-117.

64. Cherubino, M., Rubin, J. P., Miljkovic, N., Kelmendi-Doko, A., \& Marra, K. G. (2011). Adipose-derived stem cells for wound healing applications. Annals of Plastic Surgery, 66(2), 210-215.

65. Hassanshahi, A., Hassanshahi, M., Khabbazi, S., HosseiniKhah, Z., Peymanfar, Y., Ghalamkari, S., Su, Y. W., \& Xian, C. J. (2019). Adipose-derived stem cells for wound healing. Journal of cellular physiology, 234(6), 7903-7914.

66. Ryan, J. M., Barry, F. P., Murphy, J. M., \& Mahon, B. P. (2005). Mesenchymal stem cells avoid allogeneic rejection. Journal of Inflammation, 2, 8.

67. Tu, Z., Li, Q., Bu, H., \& Lin, F. (2010). Mesenchymal stem cells inhibit complement activation by secreting factor H. Stem Cells and Development, 19(11), 1803-1809.

68. Jiang, W., \& Xu, J. (2020). Immune modulation by mesenchymal stem cells. Cell Proliferation, 53(1), e12712.

69. Fu, Y., Karbaat, L., Wu, L., Leijten, J. C. H., Both, S., \& Karperien, M. (2017). Trophic effects of mesenchymal stem cells in tissue regeneration. Tissue engineering Part B: Reviews, 23(6), 515-528.

70. Wu, Y., Chen, L., Scott, P. G., \& Tredget, E. E. (2007). Mesenchymal stem cells enhance wound healing through differentiation and angiogenesis. Stem Cells, 25(10), 2648-2659.

71. Lu, T. Y., Yu, K. F., Kuo, S. H., Cheng, N. C., Chuang, E. Y., \& Yu, J. S. (2020). Enzyme-crosslinked gelatin hydrogel with adipose-derived stem cell spheroid facilitating wound repair in the murine burn model. Polymers, 12(12), 16.

72. Burmeister, D. M., Stone, R., 2nd., Wrice, N., Laborde, A., Becerra, S. C., Natesan, S., \& Christy, R. J. (2018). Delivery of allogeneic adipose stem cells in polyethylene glycol-fibrin hydrogels as an adjunct to meshed autografts after sharp debridement of deep partial thickness burns. Stem Cells Translational Medicine, 7(4), 360-372.

73. Rodrigues, C., De Assis, A. M., Moura, D. J., Halmenschlager, G., Saffi, J., Xavier, L. L., Da Cruz Fernandes, M., \& Wink, M. R. (2014). New therapy of skin repair combining adipose-derived mesenchymal stem cells with sodium carboxymethylcellulose scaffold in a pre-clinical rat model. PLoS ONE, 9(5), e96241.

74. Eylert, G., Dolp, R., Parousis, A., Cheng, R., Auger, C., Holter, M., Lang-Olip, I., Reiner, V., Kamolz, L. P., \& Jeschke, M. G. (2021). Skin regeneration is accelerated by a lower dose of multipotent mesenchymal stromal/stem cells-a paradigm change. Stem Cell Research \& Therapy, 12(1), 82.

75. Amini-Nik, S., Dolp, R., Eylert, G., Datu, A. K., Parousis, A., Blakeley, C., \& Jeschke, M. G. (2018). Stem cells derived from burned skin - The future of burn care. eBioMedicine, 37, 509-520. 
76. Später, T., Frueh, F. S., Nickels, R. M., Menger, M. D., \& Laschke, M. W. (2018). Prevascularization of collagen-glycosaminoglycan scaffolds: Stromal vascular fraction versus adipose tissue-derived microvascular fragments. Journal of Biological Engineering, 12(1), 24.

77. Formigli, L., Paternostro, F., Tani, A., Mirabella, C., Quattrini Li, A., Nosi, D., D’Asta, F., Saccardi, R., Mazzanti, B., Lo Russo, G., \& Zecchi-Orlandini, S. (2015). MSCs seeded on bioengineered scaffolds improve skin wound healing in rats. Wound Repair and Regeneration, 23(1), 115-123.

78. Fierro, F. A., O'Neal, A. J., Beegle, J. R., Chávez, M. N., Peavy, T. R., Isseroff, R. R., \& Egaña, J. T. (2015). Hypoxic pre-conditioning increases the infiltration of endothelial cells into scaffolds for dermal regeneration pre-seeded with mesenchymal stem cells. Frontiers in Cell and Developmental Biology, 3, 68.

79. Meruane, M. A., Rojas, M., \& Marcelain, K. (2012). The use of adipose tissue-derived stem cells within a dermal substitute improves skin regeneration by increasing neoangiogenesis and collagen synthesis. Plastic and Reconstructive Surgery, 130(1), 53-63.

80. Wood, F. M., Stoner, M. L., Fowler, B. V., \& Fear, M. W. (2007). The use of a non-cultured autologous cell suspension and Integra dermal regeneration template to repair fullthickness skin wounds in a porcine model: A one-step process. Burns, 33(6), 693-700.

81. Foubert, P., Barillas, S., Gonzalez, A. D., Alfonso, Z., Zhao, S., Hakim, I., Meschter, C., Tenenhaus, M., \& Fraser, J. K. (2015). Uncultured adipose-derived regenerative cells (ADRCs) seeded in collagen scaffold improves dermal regeneration, enhancing early vascularization and structural organization following thermal burns. Burns, 41(7), 1504-1516.

82. Cesarz, Z., \& Tamama, K. (2016). Spheroid culture of mesenchymal stem cells. Stem Cells International, 2016, 9176357.

83. Xu, Y., Shi, T., Xu, A., \& Zhang, L. (2016). 3D spheroid culture enhances survival and therapeutic capacities of MSCs injected into ischemic kidney. Journal of Cellular and Molecular Medicine, 20(7), 1203-1213.

84. Carter, K., Lee, H. J., Na, K. S., Fernandes-Cunha, G. M., Blanco, I. J., Djalilian, A., \& Myung, D. (2019). Characterizing the impact of 2D and 3D culture conditions on the therapeutic effects of human mesenchymal stem cell secretome on corneal wound healing in vitro and ex vivo. Acta Biomaterialia, 99, 247-257.

85. Weng, T., Zhang, W., Xia, Y., Wu, P., Yang, M., Jin, R., Xia, S., Wang, J., You, C., Han, C., Wang, X. (2021). 3D bioprinting for skin tissue engineering: Current status and perspectives. Journal of Tissue Engineering, 12, DOI: https://doi.org/10. $1177 / 20417314211028574$

86. Faulkner-Jones, A., Fyfe, C., Cornelissen, D. J., Gardner, J., King, J., Courtney, A., \& Shu, W. (2015). Bioprinting of human pluripotent stem cells and their directed differentiation into hepatocyte-like cells for the generation of mini-livers in 3D. Biofabrication, 7(4), 044102.

87. Mandrycky, C., Wang, Z., Kim, K., \& Kim, D. H. (2016). 3D bioprinting for engineering complex tissues. Biotechnology Advances, 34(4), 422-434.

88. Kim, B. S., Kwon, Y. W., Kong, J. S., Park, G. T., Gao, G., Han, W., Kim, M. B., Lee, H., Kim, J. H., \& Cho, D. W. (2018). 3D cell printing of in vitro stabilized skin model and in vivo pre-vascularized skin patch using tissue-specific extracellular matrix bioink: A step towards advanced skin tissue engineering. Biomaterials, 168, 38-53.

89. Steffens, D., Leonardi, D., Da Luz Soster, P. R., Lersch, M., Rosa, A., Crestani, T., Scher, C., De Morais, M. G., Vieira Costa, J. A., \& Pranke, P. (2014). Development of a new nanofiber scaffold for use with stem cells in a third degree burn animal model. Burns, 40(8), 1650-1660.

90. Corr, D. T., \& Hart, D. A. (2013). Biomechanics of scar tissue and uninjured skin. Advances in Wound Care, 2(2), 37-43.

91. Demirtas, Y., Yagmur, C., Soylemez, F., Ozturk, N., \& Demir, A. (2009). Management of split-thickness skin graft donor site: A prospective clinical trial for comparison of five different dressing materials. Burns, 36(7), 999-1005.

92. Patterson, C. W., Stark, M., Sharma, S., \& Mundinger, G. S. (2019). Regeneration and expansion of autologous full-thickness skin through a self-propagating autologous skin graft technology. Clinical Case Reports, 7(12), 2449-2455.

93. Schlottmann, F., Bucan, V., Vogt, P. M., \& Krezdorn, N. (2021). A short history of skin grafting in burns: From the gold standard of autologous skin grafting to the possibilities of allogeneic skin grafting with immunomodulatory approaches. Medicina, 57(3), 225.

94 Wang, C., Zhang, F., \& Lineaweaver, W. C. (2020). Clinical applications of allograft skin in burn care. Annals of Plastic Surgery, 84(3S Suppl 2), S158-S160.

95. Cissell, D. D., Hu, J. C., Griffiths, L. G., \& Athanasiou, K. A. (2013). Antigen removal for the production of biomechanically functional, xenogeneic tissue grafts. Journal of Biomechanics, 47(9), 1987-1996.

96. Lima Júnior, E. M., De Moraes Filho, M. O., Costa, B. A., Rohleder, A. V. P., Sales Rocha, M. B., Fechine, F. V., Forte, A. J., Alves, A. P. N. N., Silva Júnior, F. R., Martins, C. B., Mathor, M. B., \& de Moraes, M. E. A. (2020). Innovative burn treatment using tilapia skin as a xenograft: A phase II randomized controlled trial. Journal of Burn Care \& Research, 41(3), 585-592.

97. Rowan, M. P., Cancio, L. C., Elster, E. A., Burmeister, D. M., Rose, L. F., Natesan, S., Chan, R. K., Christy, R. J., \& Chung, K. K. (2015). Burn wound healing and treatment: Review and advancements. Critical care (London, England), 19(1), 243-243.

98. Evers, L. H., Bhavsar, D., \& Mailänder, P. (2010). The biology of burn injury. Experimental dermatology, 19(9), 777-783.

99. Davenport, L., Dobson, G., \& Letson, H. (2019). A new model for standardising and treating thermal injury in the rat. MethodsX, 6, 2021-2027.

100. Zhang, Y. Z., Li, D., Fang, S., Li, X. Y., Zhang, H. J., Dai, H. Y., Fan, H., Li, Y. L., Shen, D., Tang, W. Y., Yang, C., \& Xing, $X$. (2019). Stimulatory effect of engineered three-layer adipose tissue-derived stem cells sheet in atelocollagen matrix on wound healing in a mouse model of radiation-induced skin injury. Journal of Biomaterials Applications, 34(4), 498-508.

101. Kakabadze, Z., Chakhunashvili, D., Gogilashvili, K., Ediberidze, K., Chakhunashvili, K., Kalandarishvili, K., \& Karalashvili, L. (2019). Bone marrow stem cell and decellularized human amniotic membrane for the treatment of nonhealing wound after radiation therapy. Experimental \& Clinical Transplantation, 17(Suppl 1), 92-98.

102. Bey, E., Prat, M., Duhamel, P., Benderitter, M., Brachet, M., Trompier, F., Battaglini, P., Ernou, I., Boutin, L., Gourven, M., Tissedre, F., Créa, S., Mansour, C. A., De Revel, T., Carsin, H., Gourmelon, P., \& Lataillade, J.-J. (2010). Emerging therapy for improving wound repair of severe radiation burns using local bone marrow-derived stem cell administrations. Wound Repair and Regeneration, 18(1), 50-58.

103. Waghmare, C. M. (2012). Radiation burn-From mechanism to management. Burns, 39(2), 212-219.

104. Moan, J., Grigalavicius, M., Baturaite, Z., Dahlback, A., \& Juzeniene, A. (2015). The relationship between UV exposure and incidence of skin cancer: UV radiation and skin cancer. Photodermatology, photoimmunology \& photomedicine, 31(1), 26-35. 
105. D’Orazio, J., Jarrett, S., Amaro-Ortiz, A., \& Scott, T. (2013). $\mathrm{UV}$ radiation and the skin. International journal of molecular sciences, 14(6), 12222-12248.

106. Herndon, D. N., Barrow, R. E., Rutan, R. L., Rutan, T. C., Desai, M. H., \& Abston, S. (1989). A comparison of conservative versus early excision: Therapies in severely burned patients. Annals of surgery, 209(5), 547-553.

107. Desai, M. H., Herndon, D. N., Broemeling, L., Barrow, R. E., Nichols, J. R. J., \& Rutan, R. L. (1990). Early burn wound excision significantly reduces blood loss. Annals of surgery, 211(6), 753-762.

108. Puri, V., Khare, N. A., Chandramouli, M. V., Shende, N., \& Bharadwaj, S. (2016). Comparative analysis of early excision and grafting vs delayed grafting in burn patients in a developing country. Journal of Burn Care \& Research, 37(5), 278-282.

109. Broughton, N. G., Janis, J. E., \& Attinger, C. E. (2006). The basic science of wound healing. Plastic and reconstructive surgery (1963), 117(7 Suppl), 12-34.

110. Chen, F. M., \& Liu, X. (2016). Advancing biomaterials of human origin for tissue engineering. Progress in Polymer Science, 53, 86-168.

111. Chaudhari, A. A., Vig, K., Baganizi, D. R., Sahu, R., Dixit, S., Dennis, V., Singh, S. R., \& Pillai, S. R. (2016). Future prospects for scaffolding methods and biomaterials in skin tissue engineering: A review. International Journal of Molecular Sciences, 17(12), 1974

112. Chung, E., Rytlewski, J. A., Merchant, A. G., Dhada, K. S., Lewis, E. W., \& Suggs, L. J. (2015). Fibrin-based 3D matrices induce angiogenic behavior of adipose-derived stem cells. Acta Biomaterialia, 17, 78-88.

113. Zhong, S. P., Zhang, Y. Z., \& Lim, C. T. (2010). Tissue scaffolds for skin wound healing and dermal reconstruction. WIREs Nanomedicine and Nanobiotechnology, 2(5), 510-525.

114. Jarman-Smith, M. L., Bodamyali, T., Stevens, C., Howell, J. A., Horrocks, M., \& Chaudhuri, J. B. (2004). Porcine collagen crosslinking, degradation and its capability for fibroblast adhesion and proliferation. Journal of Materials Science: Materials in Medicine, 15(8), 925-932.

115. Jayakumar, R., Prabaharan, M., Sudheesh Kumar, P. T., Nair, S. V., \& Tamura, H. (2011). Biomaterials based on chitin and chitosan in wound dressing applications. Biotechnology Advances, 29(3), 322-337.

116. Tchemtchoua, V. T., Atanasova, G., Aqil, A., Filée, P., Garbacki, N., Vanhooteghem, O., Deroanne, C., Noël, A., Jérome, C., Nusgens, B., Poumay, Y., \& Colige, A. (2011). Development of a chitosan nanofibrillar scaffold for skin repair and regeneration. Biomacromolecules, 12(9), 3194-3204.

117. Radwan-Pragłowska, J., Piątkowski, M., Janus, Ł, Bogdał, D., Matysek, D., \& Cablik, V. (2019). 3D scaffolds prepared from acylated chitosan applicable in skin regeneration - synthesis and characterization. International Journal of Polymer Analysis \& Characterization, 24(1), 75-86.

118. Sarkar, S. D., Farrugia, B. L., Dargaville, T. R., \& Dhara, S. (2013). Chitosan-collagen scaffolds with nano/microfibrous architecture for skin tissue engineering. Journal of Biomedical Materials Research Part A, 101(12), 3482-3492.

119. Abolgheit, S., Abdelkader, S., Aboushelib, M., Omar, E., \& Mehanna, R. (2020). Bone marrow-derived mesenchymal stem cells and extracellular vesicles enriched collagen chitosan scaffold in skin wound healing (a rat model). Journal of Biomaterials Applications, 36(1), 128-139.

120. Xia, Y., Chen, J., Ding, J., Zhang, J., \& Chen, H. (2020). IGF1and BM-MSC-incorporating collagen-chitosan scaffolds promote wound healing and hair follicle regeneration. American Journal of Translational Research, 12(10), 6264-6276.
121. Ahmed, T. A. E., Dare, E. V., \& Hincke, M. (2008). Fibrin: A versatile scaffold for tissue engineering applications. Tissue engineering Part B: Reviews, 14(2), 199-215.

122. Shao, Z., Lyu, C., Teng, L., Xie, X., Sun, J., Zou, D., \& Lu, J. (2021). An injectable fibrin scaffold rich in growth factors for skin repair. BioMed Research International, 2021, 8094932.

123. Alapure, B. V., Lu, Y., He, M., Chu, C. C., Peng, H., Muhale, F., Brewerton, Y. L., Bunnell, B., \& Hong, S. (2018). Accelerate Healing of Severe Burn Wounds by Mouse Bone Marrow Mesenchymal Stem Cell-Seeded Biodegradable Hydrogel Scaffold Synthesized from Arginine-Based Poly(ester amide) and Chitosan. Stem Cells \& Development, 27(23), 1605-1620.

124. Xiong, S., Zhang, X., Lu, P., Wu, Y., Wang, Q., Sun, H., Heng, B. C., Bunpetch, V., Zhang, S., \& Ouyang, H. (2017). A gelatin-sulfonated silk composite scaffold based on 3D printing technology enhances skin regeneration by stimulating epidermal growth and dermal neovascularization. Scientific Reports, 7(1), 4288-4212.

125. Niknejad, H., Peirovi, H., Jorjani, M., Ahmadiani, A., Ghanavi, J., \& Seifalian, A. M. (2008). Properties of the amniotic membrane for potential use in tissue engineering. European Cells \& Materials, 15, 88-99.

126. Farhadihosseinabadi, B., Farahani, M., Tayebi, T., Jafari, A., Biniazan, F., Modaresifar, K., Moravvej, H., Bahrami, S., Redl, H., Tayebi, L., \& Niknejad, H. (2018). Amniotic membrane and its epithelial and mesenchymal stem cells as an appropriate source for skin tissue engineering and regenerative medicine. Artificial cells, nanomedicine, and biotechnology, 46(sup2), 431-440.

127. Stocco, E., Barbon, S., Grandi, F., Gamba, P. G., Borgio, L., Del Gaudio, C., Dalzoppo, D., Lora, S., Rajendran, S., Porzionato, A., Macchi, V., Rambaldo, A., De Caro, R., Parnigotto, P. P., \& Grandi, C. (2017). Partially oxidized polyvinyl alcohol as a promising material for tissue engineering: Novel PVA scaffolds for tissue engineering. Journal of Tissue Engineering and Regenerative Medicine, 11(7), 2060-2070.

128. Escudero-Castellanos, A., Ocampo-García, B. E., DomínguezGarcía, M. V., Flores-Estrada, J., \& Flores-Merino, M. V. (2016). Hydrogels based on poly(ethylene glycol) as scaffolds for tissue engineering application: Biocompatibility assessment and effect of the sterilization process. Journal of Materials Science: Materials in Medicine, 27(12), 176.

129. Kutikov, A. B., \& Song, J. (2015). Biodegradable PEG-based amphiphilic block copolymers for tissue engineering applications. ACS Biomaterials Science \& Engineering, 1(7), 463-480.

130. Shpichka, A., Butnaru, D., Bezrukov, E. A., Sukhanov, R. B., Atala, A., Burdukovskii, V., Zhang, Y., \& Timashev, P. (2019). Skin tissue regeneration for burn injury. Stem Cell Research \& Therapy, 10, 94.

131. Driskell, R. R., Clavel, C., Rendl, M., \& Watt, F. M. (2011). Hair follicle dermal papilla cells at a glance. Journal of Cell Science, 124(8), 1179-1182.

132. Elbialy, Z. I., Assar, D. H., Abdelnaby, A., Asa, S. A., Abdelhiee, E. Y., Ibrahim, S. S., Abdel-Daim, M. M., Almeer, R., \& Atiba, A. (2021). Healing potential of Spirulina platensis for skin wounds by modulating bFGF, VEGF, TGF- $\beta 1$ and $\alpha$-SMA genes expression targeting angiogenesis and scar tissue formation in the rat model. Biomedicine \& Pharmacotherapy, 137, 111349.

133. Jung, S.-M., Min, S. K., Lee, H. C., Kwon, Y. S., Jung, M. H., \& Shin, H. S. (2016). Spirulina-PCL nanofiber wound dressing to improve cutaneous wound healing by enhancing antioxidative mechanism. Journal of Nanomaterials, 2016, 6135727.

134. Vallejo, M. C. S., Moura, N. M. M., Gomes, A. T. P. C., Joaquinito, A. S. M., Faustino, M. A. F., Almeida, A., Gonçalves, I., Serra, V. V., \& Neves, M. G. P. M. S. (2021). The role of porphyrinoid photosensitizers for skin wound healing. International Journal of Molecular Sciences, 22(8), 4121. 
135. Darland, D. C., \& D'Amore, P. A. (1999). Blood vessel maturation: Vascular development comes of age. The Journal of Clinical Investigation, 103(2), 157-158.

136. Deuel, T. F., Kawahara, R. S., Mustoe, T. A., \& Pierce, A. F. (1991). Growth factors and wound healing: Platelet-derived growth factor as a model cytokine. Annual Review of Medicine, 42, 567-584.

137. Pierce, G. F., Mustoe, T. A., Senior, R. M., Reed, J., Griffin, G. L., Thomason, A., \& Deuel, T. F. (1988). In vivo incisional wound healing augmented by platelet-derived growth factor and recombinant c-sis gene homodimeric proteins. Journal of Experimental Medicine, 167(3), 974-987.

138. Paramasivam, T., Maiti, S. K., Palakkara, S., Rashmi, M., \& D., Manjunthaachar, H. V., Karthik, K., Kumar, N. (2021). Effect of PDGF-B gene-activated acellular matrix and mesenchymal stem cell transplantation on full thickness skin burn wound in rat model. Tissue Engineering and Regenerative Medicine, 18(2), 235-251.

139. Kim, H., Kong, W. H., Seong, K.-Y., Sung, D. K., Jeong, H., Kim, J. K., Yang, S. Y., \& Hahn, S. K. (2016). Hyaluronate-epidermal growth factor conjugate for skin wound healing and regeneration. Biomacromolecules, 17(11), 3694-3705.

140. Lee, J., Böscke, R., Tang, P.-C., Hartman, B. H., Heller, S., \& Koehler, K. R. (2018). Hair follicle development in mouse pluripotent stem cell-derived skin organoids. Cell Reports, 22(1), 242-254.

141. Lee, J., \& Koehler, K. R. (2021). Skin organoids: A new human model for developmental and translational research. Experimental Dermatology, 30(4), 613-620.

142. Ren, Y., Yang, X., Ma, Z., Sun, X., Zhang, Y., Li, W., Yang, H., Qiang, L., Yang, Z., Liu, Y., Deng, C., Zhou, L., Wang, T., Lin, J., Li, T., Wu, T., \& Wang, J. (2021). Developments and opportunities for 3D bioprinted organoids. International Journal of Bioprinting, 7(3), 364-364.

143. Xu, J., Zheng, S., Hu, X., Li, L., Li, W., Parungao, R., Wang, Y., Nie, Y., Liu, T., \& Song, K. (2020). Advances in the research of bioinks based on natural collagen, polysaccharide and their derivatives for skin 3D bioprinting. Polymers, 12(6), 1237.

144. Desanlis, A., Albouy, M., Rousselle, P., Thépot, A., Santos, M. D., Auxenfans, C., \& Marquette, C. (2021). Validation of an implantable bioink using mechanical extraction of human skin cells: First steps to a 3D bioprinting treatment of deep second degree burn. Journal of tissue engineering and regenerative medicine, 15(1), 37-48.

145. Yerra, A., \& D. M, M. (2021). Antibiotic-based silk fibroin films for burn wound healing. Polymers for Advanced Technologies, 32(2), 861-871.

146. Shen, Y.-I., Song, H.-H.G., Papa, A. E., Burke, J. A., Volk, S. W., \& Gerecht, S. (2015). Acellular hydrogels for regenerative burn wound healing: Translation from a porcine model. Journal of Investigative Dermatology, 135(10), 2519-2529.

147. Hwang, H. S., Kim, H., Han, G., Lee, J. W., Kim, K., Kwon, I. C., Yang, Y., \& Kim, S. H. (2021). Extracellular vesicles as potential therapeutics for inflammatory diseases. International Journal of Molecular Sciences, 22(11), 5487.

148. Ryan, S. T., Hosseini-Beheshti, E., Afrose, D., Ding, X., Xia, B., Grau, G. E., Little, C. B., McClements, L., \& Li, J. J. (2021). Extracellular vesicles from mesenchymal stromal cells for the treatment of inflammation-related conditions. International Journal of Molecular Sciences, 22(6), 3023.

149. Manchon, E., Hirt, N., Bouaziz, J.-D., Jabrane-Ferrat, N., \& AlDaccak, R. (2021). Stem cells-derived extracellular vesicles: Potential therapeutics for wound healing in chronic inflammatory skin diseases. International Journal of Molecular Sciences, 22(6), 3130
150. Ullah, S., Mansoor, S., Ayub, A., Ejaz, M., Zafar, H., Feroz, F., Khan, A., \& Ali, M. (2021). An update on stem cells applications in burn wound healing. Tissue \& Cell, 72, 101527.

151. Zhang, J., Guan, J., Niu, X., Hu, G., Guo, S., Li, Q., Xie, Z., Zhang, C., \& Wang, Y. (2015). Exosomes released from human induced pluripotent stem cells-derived MSCs facilitate cutaneous wound healing by promoting collagen synthesis and angiogenesis. Journal of Translational Medicine, 13(1), 49.

152. Yan, Y., Wu, R., Bo, Y., Zhang, M., Chen, Y., Wang, X., Huang, M., Liu, B., \& Zhang, L. (2020). Induced pluripotent stem cells-derived microvesicles accelerate deep second-degree burn wound healing in mice through miR-16-5p-mediated promotion of keratinocytes migration. Theranostics, 10(22), 9970-9983.

153. He, X., Dong, Z., Cao, Y., Wang, H., Liu, S., Liao, L., Jin, Y., Yuan, L., \& Li, B. (2019). MSC-derived exosome promotes M2 polarization and enhances cutaneous wound healing. Stem Cells International, 2019, 7132708.

154. Khare, D., Or, R., Resnick, I., Barkatz, C., Almogi-Hazan, O., \& Avni, B. (2018). Mesenchymal stromal cell-derived exosomes affect mRNA expression and function of B-lymphocytes. Frontiers in Immunology, 9, 3053.

155. Wang, W., Lu, K.-J., Yu, C.-H., Huang, Q.-L., \& Du, Y.-Z. (2019). Nano-drug delivery systems in wound treatment and skin regeneration. Journal of Nanobiotechnology, 17(1), 82.

156. Lai, H.-J., Kuan, C.-H., Wu, H.-C., Tsai, J.-C., Chen, T.-M., Hsieh, D.-J., \& Wang, T.-W. (2014). Tailored design of electrospun composite nanofibers with staged release of multiple angiogenic growth factors for chronic wound healing. Acta Biomaterialia, 10(10), 4156-4166.

157. Agrahari, V., Agrahari, V., Chou, M.-L., Chew, C. H., Noll, J., \& Burnouf, T. (2020). Intelligent micro-/nanorobots as drug and cell carrier devices for biomedical therapeutic advancement: Promising development opportunities and translational challenges. Biomaterials, 260, 120163.

158. Truskewycz, A., Truong, V. K., Ball, A. S., Houshyar, S., Nassar, N., Yin, H., Murdoch, B. J., \& Cole, I. (2021). Fluorescent magnesium hydroxide nanosheet bandages with tailored properties for biocompatible antimicrobial wound dressings and pH monitoring. ACS Applied Materials \& Interfaces, 13(24), 27904-27919.

159. Gholipour-Kanani, A., Bahrami, S. H., Samadi-Kochaksaraie, A., Ahmadi-Tafti, H., Rabbani, S., Kororian, A., \& Erfani, E. (2012). Effect of tissue-engineered chitosan-poly(vinyl alcohol) nanofibrous scaffolds on healing of burn wounds of rat skin. IET Nanobiotechnology IET, 6(4), 129-135.

160. Shokrgozar, M. A., Fattahi, M., Bonakdar, S., Kashani, I. R., Majidi, M., Haghighipour, N., Bayati, V., Sanati, H., \& Saeedi, S. N. (2012). Healing potential of mesenchymal stem cells cultured on a collagen-based scaffold for skin regeneration. Iranian Biomedical Journal, 16(2), 1-9.

161. Natesan, S., Zamora, D. O., Wrice, N. L., Baer, D. G., \& Christy, R. J. (2013). Bilayer hydrogel with autologous stem cells derived from debrided human burn skin for improved skin regeneration. Journal of Burn Care \& Research, 34(1), 18-30.

162. Zamora, D. O., Natesan, S., Becerra, S., Wrice, N., Chung, E., Suggs, L. J., \& Christy, R. J. (2013). Enhanced wound vascularization using a dsASCs seeded FPEG scaffold. Angiogenesis, 16(4), 745-757.

163. Gholipour-Kanani, A., Bahrami, S. H., Joghataie, M. T., Samadikuchaksaraei, A., Ahmadi-Taftie, H., Rabbani, S., Kororian, A., \& Erfani, E. (2014). Tissue engineered poly(caprolactone)chitosan-poly(vinyl alcohol) nanofibrous scaffolds for burn and cutting wound healing. IET Nanobiotechnology IET, 8(2), 123-131.

164. Leiros, G. J., Kusinsky, A. G., Drago, H., Bossi, S., Sturla, F., Castellanos, M. L., Stella, I. Y., \& Balana, M. E. (2014). Dermal 
papilla cells improve the wound healing process and generate hair bud-like structures in grafted skin substitutes using hair follicle stem cells. Stem Cells Translational Medicine, 3(10), 1209-1219.

165. Yang, Y., Zhang, W., Li, Y., Fang, G., \& Zhang, K. (2014). Scalded skin of rat treated by using fibrin glue combined with allogeneic bone marrow mesenchymal stem cells. Annals of Dermatology, 26(3), 289-295.

166. Guo, X., Xia, B., Lu, X. B., Zhang, Z. J., Li, Z., Li, W. L., Xiong, A. B., Deng, L., Tan, M. Y., \& Huang, Y. C. (2016). Grafting of mesenchymal stem cell-seeded small intestinal submucosa to repair the deep partial-thickness burns. Connective Tissue Research, 57(5), 388-397.

167. Kong, Y., Xu, R., Darabi, M. A., Zhong, W., Luo, G., Xing, M. M., \& Wu, J. (2016). Fast and safe fabrication of a free-standing chitosan/alginate nanomembrane to promote stem cell delivery and wound healing. International Journal of Nanomedicine, 11, 2543-2555.

168. Montanucci, P., di Pasquali, C., Ferri, I., Pescara, T., Pennoni, I., Siccu, P., Sidoni, A., Cervelli, V., Basta, G., \& Calafiore, R. (2017). Human umbilical cord wharton jelly-derived adult mesenchymal stem cells, in biohybrid scaffolds, for experimental skin regeneration. Stem Cells International, 2017, 1472642.

169. Motamed, S., Taghiabadi, E., Molaei, H., Sodeifi, N., Hassanpour, S. E., Shafieyan, S., Azargashb, E., Farajzadeh-Vajari, F., Aghdami, N., \& Bajouri, A. (2017). Cell-based skin substitutes accelerate regeneration of extensive burn wounds in rats. American Journal of Surgery, 214(4), 762-769.

170. Steffens, D., Mathor, M. B., Soster, P., Vergani, G., Luco, D. P., \& Pranke, P. (2017). Treatment of a burn animal model with functionalized tridimensional electrospun biomaterials. Journal of Biomaterials Applications, 32(5), 663-676.

171. Edwards, N., Feliers, D., Zhao, Q., Stone, R., Christy, R., \& Cheng, X. (2018). An electrochemically deposited collagen wound matrix combined with adipose-derived stem cells improves cutaneous wound healing in a mouse model of type 2 diabetes. Journal of Biomaterials Applications, 33(4), 553-565.

172. Gholipourmalekabadi, M., Seifalian, A. M., Urbanska, A. M., Omrani, M. D., Hardy, J. G., Madjd, Z., Hashemi, S. M., Ghanbarian, H., Brouki Milan, P., Mozafari, M., Reis, R. L., Kundu, S. C., \& Samadikuchaksaraei, A. (2018). 3D protein-based bilayer artificial skin for the guided scarless healing of third-degree burn wounds in vivo. Biomacromolecules, 19(7), 2409-2422.

173. Forbes, D., Russ, B., Kilani, R., Ghahary, A., \& Jalili, R. (2019). Liquid dermal scaffold with adipose-derived stem cells improve tissue quality in a murine model of impaired wound healing. Journal of Burn Care and Research, 40(5), 550-557.
174. Koo, M. A., Hee Hong, S., Hee Lee, M., Kwon, B. J., Mi Seon, G., Sung Kim, M., Kim, D., Chang Nam, K., \& Park, J. C. (2019). Effective stacking and transplantation of stem cell sheets using exogenous ROS-producing film for accelerated wound healing. Acta Biomaterialia, 95, 418-426.

175. Nazempour, M., Mehrabani, D., Mehdinavaz-Aghdam, R., Hashemi, S. S., Derakhshanfar, A., Zare, S., Zardosht, M., Moayedi, J., \& Vahedi, M. (2019). The effect of allogenic human Wharton's jelly stem cells seeded onto acellular dermal matrix in healing of rat burn wounds. Journal of Cosmetic Dermatology, $25,25$.

176. Samberg, M., Stone, R., 2nd., Natesan, S., Kowalczewski, A., Becerra, S., Wrice, N., Cap, A., \& Christy, R. (2019). Platelet rich plasma hydrogels promote in vitro and in vivo angiogenic potential of adipose-derived stem cells. Acta Biomaterialia, 87, $76-87$.

177. Hashemi, S. S., Pourfath, M. R., Derakhshanfar, A., BehzadBehbahani, A., \& Moayedi, J. (2020). The role of labeled cell therapy with and without scaffold in early excision burn wounds in a rat animal model. Iranian Journal of Basic Medical Sciences, 23(5), 673-679.

178. Cheng, R. Y., Eylert, G., Gariepy, J.-M., He, S., Ahmad, H., Gao, Y., Priore, S., Hakimi, N., Jeschke, M. G., \& Gunther, A. (2020). Handheld instrument for wound-conformal delivery of skin precursor sheets improves healing in full-thickness burns. Biofabrication, 12(2), 025002.

179. Thanusha, A. V., Mohanty, S., Dinda, A. K., \& Koul, V. (2020). Fabrication and evaluation of gelatin/hyaluronic acid/chondroitin sulfate/asiatic acid based biopolymeric scaffold for the treatment of second-degree burn wounds - Wistar rat model study. Biomedical Materials, 15(5), 055016.

180. Barrera, J. A., Trotsyuk, A. A., Maan, Z. N., Bonham, C. A., Larson, M. R., Mittermiller, P. A., Henn, D., Chen, K., Mays, C. J., Mittal, S., Mermin-Bunnell, A. M., Sivaraj, D., Jing, S., Rodrigues, M., Kwon, S. H., Noishiki, C., Padmanabhan, J., Jiang, Y., Niu, S., ... Gurtner, G. C. (2021). Adipose-derived stromal cells seeded in pullulan-collagen hydrogels improve healing in murine burns. Tissue Engineering Part A, 27(11-12), 844-856.

181. Roshangar, L., Rad, J. S., Kheirjou, R., \& Khosroshahi, A. F. (2021). Using 3D-bioprinting scaffold loaded with adiposederived stem cells to burns wound healing. Journal of Tissue Engineering and Regenerative Medicine, 15(6), 546-555.

Publisher's Note Springer Nature remains neutral with regard to jurisdictional claims in published maps and institutional affiliations. 